\title{
Orchard and horticulture systems in Spanish Mediterranean coastal areas: Is there a real
} possibility to contribute to $C$ sequestration?

\section{G. Pardo ${ }^{1,}{ }^{*}$, A. del Prado ${ }^{1}$, M. Martínez-Mena ${ }^{2}$, M.A. Bustamante ${ }^{3}$, J.A. Rodríguez Martín ${ }^{4}$ J.} Alvaro-Fuentes ${ }^{5} \&$ R. Moral $\left.\right|^{3}$

\footnotetext{
${ }^{1}$ Basque Centre for Climate Change (BC3), Edificio Sede № 1, Planta 1a, Parque Científico de UPV/EHU, Barrio Sarriena s/n, 48940 Leioa (Bizkaia)

${ }^{2}$ Soil and Water Conservation Dpt, CEBAS, Spanish National Research Council (CSIC), Campus Universitario de Espinardo, PO Box 164, 30100 Murcia, Spain

${ }^{3}$ Agrochemistry and Environment Dpt, Miguel Hernandez University (UMH), EPS-Orihuela, Ctra Beniel
} Km 3.2, 03312 Orihuela, Spain

${ }^{4}$ Dept. Environment, Instituto Nacional de Investigación y Tecnología Agraria y Alimentaria (I.N.I.A), Ctra. de A Coruña 7.5, 28040, Madrid, Spain

${ }^{5}$ Soil and Water Dpt, Estacion Experimental de Aula Dei (EEAD), Spanish National Research Council (CSIC,), Av. Montañana, 1005, 50059 Zaragoza, Spain

"Corresponding author. Tel.: +34 944014690; fax: +34 944054787

Email adress: guillermo.pardo@bc3research.org (G.Pardo)

Agriculture in the Mediterranean basin is currently contributing to greenhouse gas emissions (GHG) and in the future is expected to be strongly affected by climate change. Increasing soil organic carbon (SOC) via soil organic matter (SOM) improvement is widely regarded as a way to both mitigate and adapt to climate change. Using as a case study the Mediterranean coastal area in Spain, which is regarded as one of the most intensively managed areas in Europe for orchards and horticultural cropping, we analyzed the potential for climate change mitigation of introducing different practices that are expected to increase SOC. We selected both as a single 
measure and in combination, cover cropping and application to the soil of the available underutilized exogenous organic matter (EOM), treated (e.g. composted or digested) or nontreated. These practices were compared against a baseline scenario that intended to reflect the current practices in the area (e.g. all livestock manure produced in the area is applied to the agricultural soil). We carried out a modelling exercise at the regional scale using the agricultural activity data and current climatic conditions as inputs. Modelling runs were performed coupling a widely used dynamic model of SOC turnover (RothC) with a model to simulate the GHG emissions from EOM processing or storage prior to soil application (SIMS WASTE).

Results indicate that the most promising practice, considered as a single measure and with respect to the baseline, was introducing cover crops in woody cropping systems. This practice resulted in an increase of $0.44 \mathrm{Mg} \mathrm{C} \mathrm{ha}^{-1} \mathrm{yr}^{-1}$ during the first 20 years (range $0.41-0.52 \mathrm{Mg} \mathrm{C}^{-}$ $\left.{ }^{1} \mathrm{yr}^{-1}\right)$ and led to a total SOC accumulation of about $30 \mathrm{Tg} C$ after 100 years. Amendment of all agricultural land with available underutilized EOM resulted in an increase of up to $0.09 \mathrm{Mg} \mathrm{C}$ $\mathrm{ha}^{-1} \mathrm{yr}^{-1}$ (range $0.07-0.16 \mathrm{MgC} \mathrm{ha}^{-1} \mathrm{yr}^{-1}$ ) as a single measure (urban waste) and $0.13 \mathrm{Mg} \mathrm{Cha}$ $\mathrm{yr}^{-1}$ (range 0.11-0.21 Mg C ha-1 $\mathrm{yr}^{-1}$ ) as a combined measure (urban waste and composted agroindustry by-products), leading to a total SOC accumulation of about $7 \mathrm{Tg}$ C (urban waste) and $10 \mathrm{Tg} C$ (urban waste and composted agroindustry by-products) after 100 years. Manure anaerobic digestion or composting as a single measure did not result in significant SOC changes but, if GHG emissions and savings from manure storage and processing management stages are considered, they could help to reduce about 4.3 (anaerobic digestion) or $1.1 \mathrm{Tg} \mathrm{CO}_{2} \mathrm{eq} \mathrm{yr}^{-1}$ (composting) in the study area, which represents a significant amount compared with total agricultural emissions in Spain. 


\section{Introduction}

Agriculture plays different roles in relation to climate change. On one hand, agriculture is particularly sensitive to the impact of climate change, and on the other hand, agriculture is responsible for about 10-12 \% of total man-made greenhouse gases emissions (Smith et al., 2014). Moreover, agriculture has also a climate change mitigating role as it can potentially act as a sink of atmospheric carbon (C) via, for example, soil organic carbon (SOC) sequestration. Anthropogenic activities, such as agricultural management, soil characteristics and climate are the main regulating factors affecting SOC changes (Farina et al., 2011).

One of the most important areas for agriculture in the world is the Mediterranean basin, where agriculture covers around $21 \mathrm{M}$ ha located in the south of Europe and north of Africa. In general, Mediterranean agriculture is largely affected by a long summer drought and rainfall is, in most areas, confined to the autumn, winter and spring seasons. Unless field crops are irrigated they must either be sown in the autumn and harvested by early summer, or be capable of resisting drought. There are also comparatively mild winters and hot, sunny summers. Temperatures are such that a variety of temperate crops can be grown in the rainy season, and - with irrigation - sub-tropical crops in the summer (Grigg, 1974). In Spain, although subsistence agriculture occurs side by side with commercial farming, Mediterranean farming is generally intensive, highly specialised and varied in the kinds of crops raised. Many horticultural crops and orchards such as citrus, fruits, olives, and grapes are mainly for export and are largely grown in the Spanish Mediterranean coastal areas. Intensive agriculture negatively affects soil fertility mainly because of a loss in soil organic matter (SOM). Furthermore, the abundant use of fertilizers and pesticides used also increases the risk that nutrients and pesticides run-off into surface and leach into groundwater (Eurostat, 2015).

The specific conditions of this Spanish area (i.e. low water availability limiting crop growth, difficult land recovery after degradation, potentially high mineralization rates) make it especially sensitive to perturbations (e.g. those resulting from climate change). Although this 
particular setting can be a barrier for soil $\mathrm{C}$ sequestration, if measures to promote SOM are introduced, there are opportunities to largely increase soil C due to the high range of stocking capacity of these soils.

Several management options and farming practices have been proposed to enhance SOC accumulation by either increasing inputs (manure, compost and other recycled organic materials) or decreasing losses, e.g. stubble retention. Agricultural conservation practices (e.g. no-tillage and mulching, cover cropping, the introductions of crop rotations with high diversity, integrated nutrient management) or irrigation are amongst the practices that have been identified in order to sequester SOC in agricultural systems (Lal, 2004). These practices are, in fact, a reliable and effective way to improve soil structure and both chemical and biological fertility of soils.

In the Mediterranean area, in general, soil organic C stock is constrained by factors such as limited C input, long-term practices of intensive tillage combined with the use of long bare fallows and the removal of crop residues for animal feed (Álvaro-Fuentes and Paustian, 2011). However, there are still large amounts of exogenous organic matter (EOM), i.e. C inputs, which are underutilized as soil amendments.

In Mediterranean conditions, even though SOM models have already been used to predict SOC changes in agroecosystems (e.g. Álvaro-Fuentes et al., 2012a; Francaviglia et al., 2012; Liu et al., 2009; Mondini et al., 2012; Nieto et al., 2010) to our knowledge there is not such study that evaluates the effect on SOC accumulation of applying different EOM that are currently not used for agriculture, treated (e.g. compost or digestate) or non-treated (e.g. sewage sludge) in combination with other measures (cover cropping). Accordingly, here we present a modelling study in which the effects on SOC accumulation are investigated in a case study covering the Mediterranean costal area in Spain, which is a representative area of large horticulture and woody crops agricultural production within the Mediterranean climatic conditions. 


\section{Contextualisation of study area}

\subsection{Climate}

The studied area covers the provinces that are situated along the entire Spanish Mediterranean coast, comprising mainly Meso-Mediterranean and Thermo-Mediterranean bioclimatic zones (Figure 1) (Rivas-Martínez \& Rivas-Saenz, 2016). The thermo-Mediterranean zone is characterized by hot summers and mild winters with almost absence of frosts. It covers lowlands and littoral areas, and concentrates most of the citrus and horticultural production in the Iberian Peninsula. The Meso-Mediterranean zone, which is associated to inland areas, also involves hot summers but cool winters and frosts are likely.

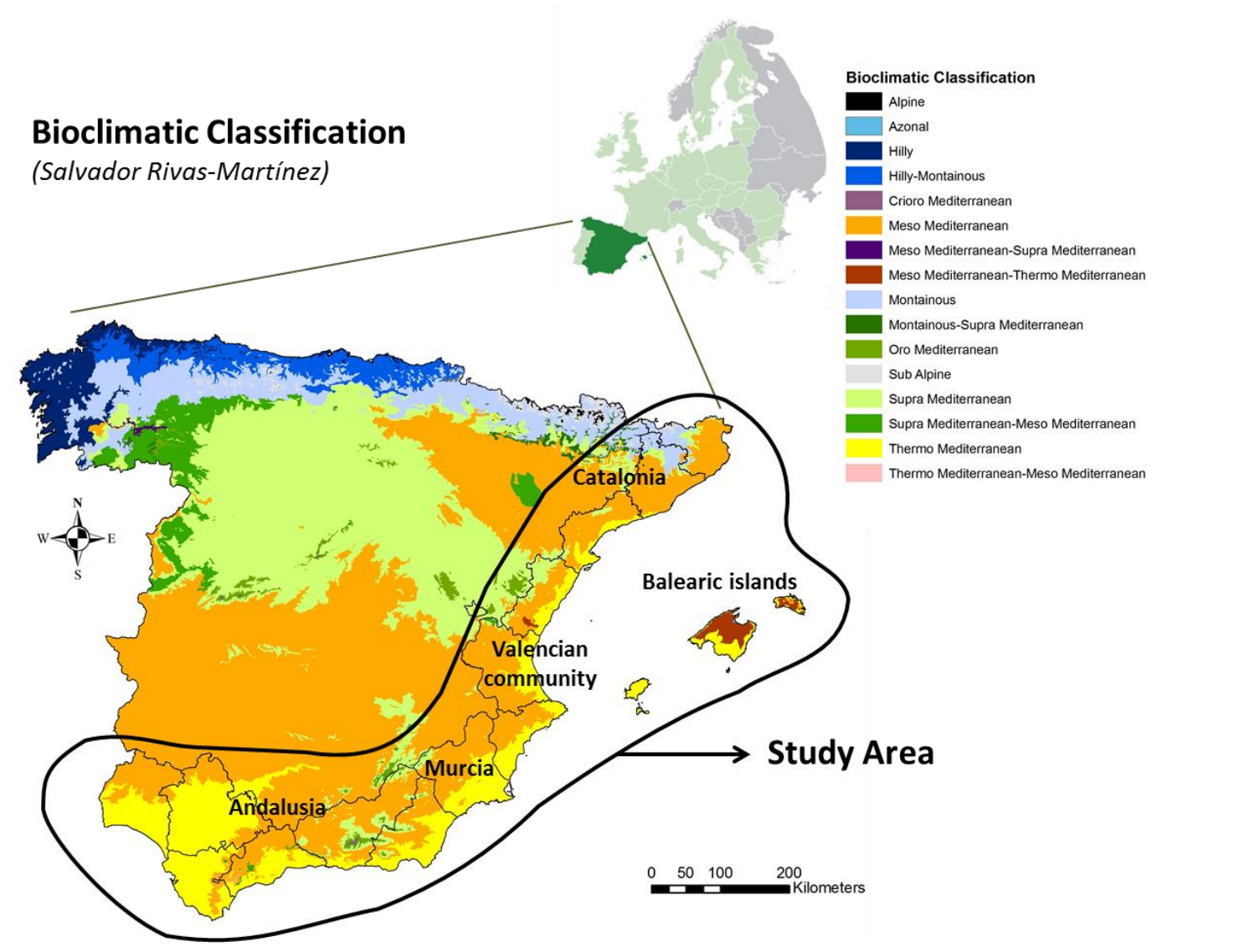

Figure 1. Bioclimatic areas in Spain based on Rivas-Martínez \& Rivas-Saenz (2016). Area of study comprises the Spanish Mediterranean coastal provinces. The names of the Autonomous Communities involved is indicated 
Within the study area there is large variability in precipitation regimes, with annual rainfall ranges between 200 and $600 \mathrm{~mm}$. Precipitation concentrates during the winter, autumn and spring seasons, often in the form of heavy storms. In contrast, droughts are frequent during hot summer months, involving water stress in plants and the need for irrigated agriculture (Mancinelli et al., 2013).In the coming decades, the Mediterranean basin is most likely to be strongly affected by the impacts of climate change (IPCC, 2013; Kushnir, 2015; Ludwig and Roson, 2016; Ozturk et al., 2015).

\subsection{Soils}

The soils in the studied area are mainly alkaline carbonated Aridisols (ranged from $40-70 \%$ depending region), Inceptisols and Entisols in accordance to USDA soil classification (Soil Survey Staff, 2014). These well-aerated soils, with light soil textures, produce high efficient conditions for OM oxidation, accelerated by tillage and irrigation in agricultural soils (Balesdent et al, 1990; Trost et al, 2013). The SOM content and natural humic pools for the studied area are very low, based on the study from Rodríguez Martín et al. (2016). In Figure 2, SOC stock for the study area is shown. Soils with large clay concentration are associated with increased SOC stabilization potential (Sollins et al., 1996). In the study area the average content of clay is about 22\%, although wide differences are observed depending on regions (Catalonia 19.1\%; Valencian community 21.9\%; Murcia 25.7\%; Andalusia: Almeria 15.6\%, Cadiz-Malaga 31.6\%), which lead to different opportunities for the stabilization of SOC. Additionally, other soil characteristics found in these soils, e.g. enhanced physical protection of organic $\mathrm{C}$ by soil aggregates (microaggregates inside macroaggregates), in combination with physical and chemical mechanisms also increase the potential to sequester SOC in the study area (AlvaroFuentes et al., 2008; García-Franco et al., 2015) . 
The Mediterranean agriculture in general and the study area in particular are very vulnerable to soil erosion, especially by water (Boix-Fayos et al., 2005; García-Ruiz, 2010), because of geo-ecological factors (lithology, topography, and climatology) and also the land use history and plant cover changes. Geographically, in the Andalusia region, about $20 \%$ of the surface is classified as "high erosion risk" with a mean annual soil loss of $23.2 \mathrm{Mg} \mathrm{ha}^{-1}$ (Rodríguez-Martín et al., 2016). In other regions in the study area erosion losses have been estimated at $23.7 \mathrm{Mg}$ $\mathrm{ha}^{-1} \mathrm{yr}^{-1}$ in Catalonia, $16.8 \mathrm{Mg} \mathrm{ha} \mathrm{yr}^{-1} \mathrm{yr}^{-1}$ Valencia and 17.6 $\mathrm{Mg} \mathrm{ha}^{-1} \mathrm{yr}^{-1}$ in Murcia (MAGRAMA, 2015). This soil loss has been found to represent soil $C$ losses at rates ranging from 0.008 to 0.3 $\mathrm{Mg} \mathrm{C} \mathrm{ha-1} \mathrm{yr}^{-1}$ under orchard trees crops, for example, in the study area (Martínez-Mena et al. 2008; Nieto et al., 2012).

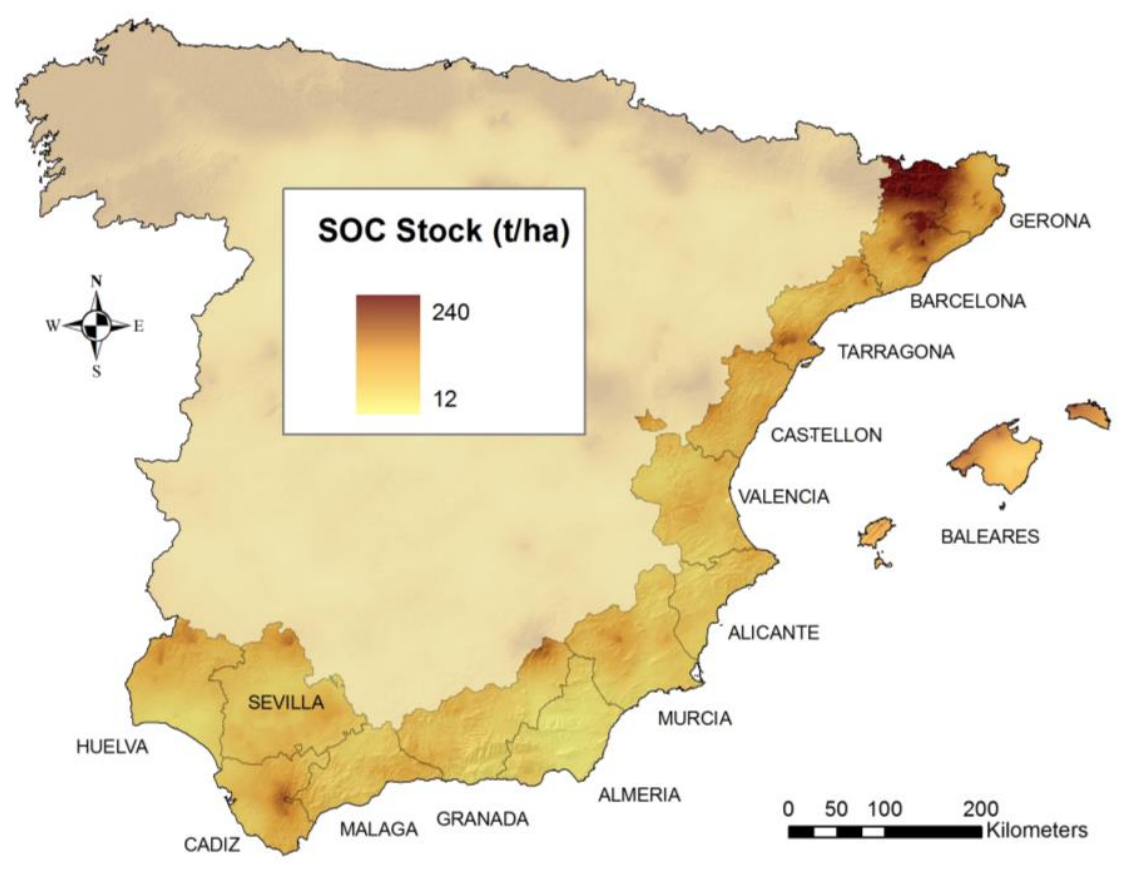

Figure 2. Soil Organic Carbon stock in the provinces comprising the study area. Map extracted and modified from Rodriguez-Martin et al. (2016) 


\subsection{Crop productivity and plant residues}

Woody crops and horticulture are the prevailing agricultural land uses in the Spanish Mediterranean coastal regions (MAGRAMA, 2013). Rainfed and low water-intensive systems are predominant in the inland areas (i.e. in Meso-Mediterranean zone), mainly for the production of some characteristic woody crops such as olive (Olea europea L.), vine (Vitis vinifera L.) and almond (Prunus dulcis Mill.). The large annual variability in precipitation and temperature together with high evapotranspiration rates leads to a low crop biomass productivity, and thus to a limited plant residue input into the soil (Álvaro-Fuentes et al., 2008). These systems, characterized by low input use (i.e. fertilization), are mainly represented by olive groves, vineyards and nut trees orchards with annual crop yields about $1.6 \mathrm{Mg}, 7.6 \mathrm{Mg}$ and $1.1 \mathrm{Mg} \mathrm{ha}^{-1}$ respectively in fresh matter (FM) (MAGRAMA, 2013). Managed in a conventional way, the biomass output in these systems is usually greater than the input as pruning remains are traditionally burned and other debris are removed through the fruit harvest and not returned to the soil. As a result an overall loss of $\mathrm{C}$ is produced, which leads to low SOC contents.

In littoral areas (i.e. in Thermo-Mediterranean areas) agriculture is more intensively managed and irrigated, producing fruit and vegetables for fresh consumption (Fernández-Zamudio, 2006). Irrigated intensive orchard and horticultural systems are highly productive and hence, they can produce large $C$ inputs as plant residues. Thus, citrus and other fruit trees, which involve seasonal irrigation and moderate fertilization, achieve annual crop yields of 20.8 and 9.7 Mg FM ha-1 respectively, and values about 26.1 $\mathrm{Mg} \mathrm{FM} \mathrm{ha}^{-1}$ are obtained for horticultural crops through the use of intensive irrigation or fertigation, and high inputs of fertilizers and xenobiotics (MAGRAMA, 2013). 


\subsection{Exogenous organic matter}

Exogenous organic matter (EOM) is defined as the wide variety of organic waste generated from agricultural (e.g. manure), urban (e.g. sewage sludge), or industrial (Marmo et al., 2004) activities which is suitable for agricultural application. Table 1 summarizes the annual production and main sources of this EOM in Spain and in the studied area, together with a raw estimate of their agricultural availability and biodegradability. In the Spanish Mediterranean coastal area animal manure comprises a very large waste stream, with over $12.7{\mathrm{Tg} \mathrm{FM} \mathrm{yr}^{-1}}^{-1}$ (MARM, 2009). During the last two decades, the development and expansion capacity of recovery facilities for municipal solid waste (MSW) and urban wastewater have generated an increasing stream of EOM in the Spanish Mediterranean area $(>600 \mathrm{Gg})$, mainly in the form of compost and sewage sludge (MAGRAMA, 2011). Currently, a major part of these urban waste streams (about $80 \%$ ) are applied on agriculture, often on intensive horticulture and orchards (i.e. citrus trees) but its generation is concentrated around cities and high populated areas, which may represent a constraint for an optimized utilization (MAGRAMA, 2011).

Remarkable production of fruits and vegetables in the Spanish Mediterranean coastal regions has enhanced the development of different industrial activities around the agri-food sector, which also represent a source of organic wastes with varied characteristics depending on the production process (e.g. olive oil industry, wine industry, vegetable-processing industry) (Alburquerque et al., 2004; Bustamante et al., 2008; Morales et al., 2016). These organic resources are only partially valorized at different value-added levels (animal feed, bioenergy, composting) resulting in large volumes of organic resources managed as waste ultimately (Federici et al., 2009). 
Table 1. Estimation of organic matter resources from waste streams in Spain and in the studied area

\begin{tabular}{|c|c|c|c|c|c|}
\hline Sector & Source of residues & $\begin{array}{l}\text { Production } \\
\text { Spain } \\
\text { Gg } C y r^{-1}\end{array}$ & $\begin{array}{c}\text { Production } \\
\text { Study area } \\
\text { Gg } C y^{-1}\end{array}$ & Agricultural availability & Biodegradability \\
\hline \multirow[t]{5}{*}{ Agriculture } & Cereal crops ${ }^{1}$ & 9,173 & 1,334 & Low & Medium \\
\hline & Oil crops ${ }^{1}$ & 443 & 138 & Low & Medium \\
\hline & Industrial crops ${ }^{1}$ & 114 & 49 & Low & Medium \\
\hline & Woody crops ${ }^{1}$ & 2,959 & 1,109 & Medium & Low \\
\hline & Vegetables $^{1}$ & 553 & 297 & Medium & Medium \\
\hline \multirow[t]{4}{*}{ Livestock } & Pig slurry ${ }^{2}$ & 1,239 & 406 & High & High \\
\hline & Cow manure ${ }^{2}$ & 2,669 & 345 & High & Medium \\
\hline & Poultry manure ${ }^{2}$ & 253 & 94 & High & High \\
\hline & Other species ${ }^{2}$ & 1,527 & 294 & High & Medium \\
\hline \multirow[t]{3}{*}{ Urban waste } & Compost (MSW) ${ }^{3}$ & 92 & 58 & High & Low \\
\hline & Compost (Source segregated MSW) ${ }^{3}$ & 73 & 38 & High & Low \\
\hline & Sewage sludge 3 & 375 & 174 & High & Medium \\
\hline \multirow[t]{8}{*}{ Food industry } & Market withdrawals ${ }^{4}$ & 59 & 41 & Low & High \\
\hline & Rejected products ${ }^{4}$ & 22 & 14 & Low & High \\
\hline & Processing industries ${ }^{4}$ & 72 & 53 & Medium & High \\
\hline & Olive oil industry: olive mill waste ${ }^{4}$ & 737 & 171 & High & Medium \\
\hline & Brewery industry ${ }^{4}$ & 96 & 53 & Low & High \\
\hline & Winery-distillery industry ${ }^{4}$ & 48 & 8 & High & Medium \\
\hline & Sugar industry ${ }^{4}$ & 34 & 13 & High & High \\
\hline & Agri-food sludge 4 & 9 & 4 & High & Medium \\
\hline
\end{tabular}

${ }^{1}$ Own estimation based on crop production and surface area data from the Spanish Agricultural Yearbook (MARM (Ministerio de Medio Ambiente y medio Rural y Marino) 2009). ${ }^{2}$ Own estimation based on livestock data from the Agricultural Statistical Yearbook (MARM (Ministerio de Medio Ambiente y medio Rural y Marino) 2009); ${ }^{3}$ (MAGRAMA (Ministerio de Agricultura, Alimentación y Medio Ambiente) 2011); ${ }^{4}$ www.probiogas.es; (A thorough description of the estimation methodology used can be found in the section Methods and in the Supplementary Material) 


\subsection{Soil organic matter mineralization}

In the study area mineralization rates are very high and soil respiration is one of the main processes of $\mathrm{C}$ loss. Values of $\mathrm{CO}_{2}$ emissions under orchard have been estimated around $5 \mathrm{Mg}$ C ha-1 $\mathrm{yr}^{-1}$ (Almagro et al., 2010; Nieto et al., 2012).

Table 2 summarizes the results from different studies analyzing the percentage of organic $C$ mineralized in soil of different EOM (organic wastes and composts) from different sources (details are available in the Supplementary Material (Table S2)). These studies were carried out mainly under Mediterranean soils with light soil textures, alkaline $\mathrm{pH}$ and high contents in carbonates (representative of the most widespread soils in the study area). The results of these studies show the high variability in the mineralization percentages depending on the type of organic waste and, especially, on the degree of stabilization. For example, raw wastes present on average, almost twice potential percentage of mineralized organic $\mathrm{C}$ as much as the composted organic wastes. Non-treated wastes also show larger variability in the mineralization percentage values than composted materials, due to the higher OC stabilization in the composted ones. In the raw wastes, the agricultural and livestock wastes have, in general, higher potential percentage of mineralized $C$ (average mineralization percentage between 34 and $40 \%$ ) than those from urban and agro-industrial origin (average values oscillating between 18 and 20\%). Within the composted materials, municipal solid wastes and anaerobic digestates present the lowest mineralization C percentage (mean values oscillating between 3 and 9\%).

\subsection{Management practices}

In Mediterranean Spain, during the last two decades conservation agriculture has gained importance as a viable alternative to the traditional farming systems. In 2012, the orchard Spanish surface managed with minimum tillage was about $44 \%$ of the total surface. 
Furthermore, cover cropping (either as natural vegetation or sown crop) was used in the $24 \%$ of the total agricultural surface (MAGRAMA, 2013). When the previous data are disaggregated and analysed for the different tree crops important differences existed in the proportion of surface occupied with conservation agriculture practices. For instance, olive orchards represented the $50 \%$ and $40 \%$ of the total orchard surface with minimum tillage and cover crops, respectively. However, in citrus orchards the same proportions dropped to $2 \%$ and $5 \%$, respectively (MAGRAMA, 2013). 
Table 2. Percentage of organic $\mathrm{C}$ mineralized in soil of raw and composted organic wastes from different origin.

\begin{tabular}{|c|c|c|c|c|}
\hline & $\begin{array}{l}\text { Type of organic } \\
\text { material }\end{array}$ & $\begin{array}{c}\text { Mean value of } \\
\text { mineralisation } \\
\text { (\% added organic C) }\end{array}$ & $\begin{array}{l}\text { Range of mineralisation } \\
\text { (\% added organic } \mathrm{C})\end{array}$ & Sources \\
\hline \multicolumn{5}{|l|}{ Raw organic wastes } \\
\hline \multirow[t]{3}{*}{ Agricultural and vegetal wastes } & Cereal crops & 36.2 & $12-58$ & $(1),(2),(3)$ \\
\hline & Other crops & 40.2 & $5.2-65.0$ & $(1),(4),(5),(6)$ \\
\hline & Other vegetal species & 26.7 & $5-75$ & (7), (8), (9) \\
\hline \multirow[t]{2}{*}{ Livestock wastes } & Manure & 44.1 & $12-90$ & $(1),(2),(6),(10),(11),(12)$ \\
\hline & Slurry & 34.9 & $20.0-49.8$ & (3), (13) \\
\hline \multirow[t]{2}{*}{ Urban wastes } & Municipal solid waste & 15.2 & $8.9-25.8$ & (14) \\
\hline & Sewage sludge & 20.0 & $8-26$ & $(15),(16)$ \\
\hline \multirow[t]{3}{*}{ Agro-industrial wastes } & Agri-food waste & 15.3 & $9.4-21.8$ & $(17)$ \\
\hline & Anaerobic digestate & 38.1 & $16.1-63.0$ & $(13),(18)$ \\
\hline & Biochar & 6.1 & $1.9-10.0$ & (19), (20), (21) \\
\hline \multicolumn{5}{|l|}{ Composted organic wastes } \\
\hline Livestock wastes & Manure/slurry & 13.1 & $2.9-24.3$ & $(6),(22)$ \\
\hline \multirow[t]{2}{*}{ Urban wastes } & Municipal solid waste & 8.8 & $2.1-45.3$ & $(10),(14),(22),(23)$ \\
\hline & Sewage sludge & 19.2 & $3-37.9$ & $(10),(15),(16),(22)$ \\
\hline \multirow[t]{2}{*}{ Agro-industrial wastes } & Agri-food waste & 11.1 & $1.7-21.4$ & $(24),(25),(26)$ \\
\hline & Anaerobic digestate & 2.9 & 2.9 & (13) \\
\hline
\end{tabular}




\section{Methods}

\subsection{Models description}

\subsubsection{RothC model}

The Rothamsted carbon (RothC) model (Coleman and Jenkinson, 1996) is one of the most widely used models to simulate SOC dynamics. RothC has been evaluated in a variety of ecosystems such as croplands, grasslands and forests (Coleman et al., 1997; Falloon and Smith, 2002; Johnston et al., 2009; Powlson et al., 2011; Smith et al., 1997) and under different soil types and climatic conditions, including semi-arid environments (Álvaro-Fuentes et al., 2012b; Francaviglia et al., 2012; Jenkinson et al., 1999; Skjemstad et al., 2004). It has been used to make national and global scale SOC predictions in a variety of studies (Falloon and Smith, 2002; Falloon et al., 1998b; Post et al., 1982; Smith et al., 2005; Tate et al., 2000) and also to simulate the effect of organic amendment addition (e.g. manure application) on changes in SOC stocks (Coleman et al., 1997; Mondini et al., 2012; Yokozawa et al., 2010).

A detailed description of the model is given by Coleman and Jenkinson (1996). RothC's simulation runs are based on relatively few parameters and input data that are readily available (Smith et al., 1997): soil type, temperature, moisture content and plant cover. Soil organic carbon is split into four active fractions and one small inert organic matter (IOM) fraction. The active fractions are: decomposable plant material (DPM), resistant plant material (RPM), microbial biomass (BIO), and humified organic matter (HUM). Each fraction decomposes by a first-order process with its own characteristic rate, while the IOM fraction is considered to be resistant to decomposition

\subsubsection{SIMS WASTE model}

The SIMS waste model (Pardo et al., 2013; Pardo et al., 2017) is used to simulate the $C$ and nutrient $(\mathrm{N}, \mathrm{P}, \mathrm{K})$ transformations (emissions and flows to end-products) associated with 
different processing technologies for organic waste, mainly anaerobic digestion and composting. The performance of the biological process is considered to be influenced by two main factors: substrate composition and operational conditions. As the main parameters for the model, flow of each organic source (on a yearly basis), the basic chemical composition ( $\mathrm{N}$, $\mathrm{NH}_{4}{ }^{+}-\mathrm{N}, \mathrm{P}, \mathrm{K}$ ) and the substrate organic compounds (i.e. carbohydrates, lignin, proteins and lipids) have to be detailed if available (reference values are used otherwise).

Based on the substrate composition, biodegradable volatile solids (BVS) are divided in two major pools characterized by labile (BVS labile $_{\text {) }}$ or resistant (BVS resistant) biodegradability. The potential influence of operational parameters is considered through reaction rate constants $\left(\mathrm{K}_{\mathrm{f}}, \mathrm{K}_{\mathrm{s}}\right)$ as a measure of the overall efficiency of the biological process under specific conditions. They correspond to first-order reaction rate constants $\left(k_{f}, k_{s}\right)$ observed in the bibliography for

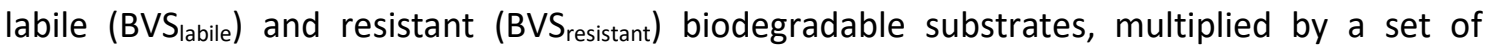
factors related to operational and environmental conditions. $\mathrm{N}$ and $\mathrm{P}$ mineralization are estimated according to the decomposition rate of proteins. Gaseous losses of $\mathrm{N}$ forms are accounted on the basis of the ammonium- $\mathrm{N}\left(\mathrm{NH}_{4}{ }^{+}-\mathrm{N}\right)$ content, through different emission factors (EFs) established for $\mathrm{NH}_{3}-\mathrm{N}$ and $\mathrm{N}_{2} \mathrm{O}-\mathrm{N}$. Finally, amount and composition of the main outputs (i.e. biogas, digestate, compost) are provided, as well as emissions and energy (consumed or produced) associated with the processing technology analysed.

SIMS WASTE has been applied to simulate carbon (C) and nitrogen (N) flows from manure and food by-products management processes according to different treatments (e.g. composting, anaerobic digestion), operational conditions and specific substrate compositions (del Prado et al., 2013; Pardo et al. 2017). 


\subsection{Study area}

The studied area covers the entire Spanish Mediterranean coast, related to ThermoMediterranean and Meso-Mediterranean climates (Figure 1). It includes 14 coastal provinces of Catalonia, Valencian community, Murcia, Andalusia, and Balearic Islands. With a total of 2.6 Mha, the cropping structure could be divided in three main classes in terms of intensification considering irrigation, fertilizer-amendments, other crop inputs and tillage:

a) Low intensification: mainly rainfed, one tillage per year, 1-2 organic amendments to soil per year, low to no inorganic fertilization. Mainly olive groves and vineyards

b) Medium intensification: seasonal irrigation, seasonal tillage, 2-3 organic amendments to soil per year. Mainly citrus and fruit trees.

c) High intensification: intensive irrigation or fertirrigation, 4-6 tillage operations per year. High input of inorganic fertilizers and xenobiotics, use of fresh OM for sanitization every 3 years. Mainly horticulture.

Based on this structure, five land use classes were selected for the analysis of scenarios: horticulture, citrus trees, fruit trees, olive groves and vineyards.

\subsection{Data sets}

Information on regional crop production and surface area was obtained from the Spanish Agricultural Yearbook (MARM, 2009).

Mean SOC stocks in $\mathrm{Mg} \mathrm{ha}^{-1}$ to $30 \mathrm{~cm}$ depth and the percentage clay content in that layer were estimated for each province, derived from Rodríguez Martín et al. (2016).

Monthly average temperature and precipitation data for the selected Spanish provinces were extracted from the AEMET (2012) for the range 1961-2010. Monthly potential 
evapotranspiration (PET) was calculated from the air temperature precipitation and diurnal temperature range data according to Hargreaves method (Allen et al., 1998).

Carbon inputs from animal manure application were calculated as follows. First, the livestock population of each animal category (pigs, dairy cattle, non-dairy cattle, sheep, goats and poultry) for 2008 was obtained from the data set of the Spanish Ministry (MARM, 2009) for each province. Dry matter excretion rates $\left(\mathrm{kg} \mathrm{place}^{-1} \mathrm{yr}^{-1}\right)$ for animal housing were derived for the base year from the National Inventory Report (MAGRAMA, 2011) and converted to C by assuming $80 \%$ content of volatile solids (VS) and $55 \%$ of C content in VS (Adams et al., 1951). The $C$ excreted by outdoor grazing animals, which in this study represents a small fraction, was deducted from the total by applying the factor proposed by the National Inventories (UNFCCC, 2014), as that manure was assumed to reach mainly grasslands which are not included in the present study. Finally we distributed the manure applied to available crops proportionally according to their share of surface area in each province.

Agricultural application of urban waste involved two waste streams: compost from municipal solid waste and sewage sludge. For each province, production data (on a dry matter basis) at biological treatment plants was obtained (MAGRAMA, 2011) and transformed into $C$ inputs by assuming $55 \%$ of $C$ content (Adams et al., 1951)

Regional availability of organic by-products from agri-food industries was obtained from biomass inventories of PROBIOGAS project (http://www.probiogas.es/), including total amount and composition.

\subsection{Simulation procedure}

For each province and land use combinations considered in the study, the initial SOC content was set to the 2010 values (Rodríguez Martín et al., 2016) and then the changes in SOC with 
time were simulated for different management scenarios, which will be described in detail later.

Specific RothC input files involving soil characteristics (SOC, \%clay) and meteorological data were created for every province and land use combination. Additionally, monthly irrigation water was considered where applicable, according to the common practices in the area of the study. It was accounted as an additional water input in the monthly precipitation data. Plant cover was assumed to occur all year round in horticulture croplands, as successive crop cycles are produced along the year. For woody crops, the entire surface was considered to be covered year round too, as C is continually supplied by the roots (Nieto et al., 2012).

In the baseline scenario, SOC was assumed to have reached equilibrium ( $>30$ years with the same management). As described by Coleman and Jenkinson (1996), the RothC model was run to equilibrium under constant environmental conditions (average climate data for 1961-2010) in order to obtain the annual $\mathrm{C}$ inputs to the soil to maintain the measured amount of SOC. In this calculation process, the initial C content of the different SOC pools (DPM, RPM, BIO, HUM and IOM) is determined.

The monthly distribution of $\mathrm{C}$ inputs was estimated following the procedure described by in previous works (Mondini et al., 2012; Smith et al., 2005). First, the total annual plant input and the proportions of plant material added monthly to the soil were set to describe the typical pattern of inputs for each land use class considered (Table S3). For woody crops, we assumed $70 \%$ of the plant inputs occurring in the pruning period and the remaining $30 \%$ during the four previous months. For horticulture, $50 \%$ of plant inputs were assigned to the summer period, and the rest were distributed along the remaining months, as successive harvest cycles usually occur along the year. Additionally, a $\mathrm{C}$ input of animal manure was assumed according to the regional availability (range $0.1-2.0 \mathrm{MgC} \mathrm{ha}^{-1} \mathrm{yr}^{-1}$ ) as periodical manure addition has been traditionally a common practice in the area of study. DPM: RPM ratios of 1.44 and 0.25 were 
used for plant residues of horticulture and woody crops respectively, as suggested in literature for agricultural crops and deciduous woodland (Coleman and Jenkinson, 1996). The recommended values for manure (DPM=49\%, RPM=49\%, HUM=2\%) were also applied (Coleman and Jenkinson, 1996).

Once RothC was run to equilibrium, the annual $C$ input was adjusted to give the measured soil C content provided in the soils database using the following equation:

$P_{\text {req }}=P_{i} \times\left[\frac{\left(C_{\text {meas }}-I O M\right)}{\left(C_{\text {sim }}-I O M\right)}\right]$

where $P_{\text {req }}$ is the required annual $C$ input, $P_{i}$ is the initial annual $C$ addition, $C_{\text {meas }}$ is the measured SOC given in the soils database, $\mathrm{C}_{\text {sim }}$ is the simulated soil $\mathrm{C}$ after the equilibrium run, and the IOM is the $\mathrm{C}$ content of the inert organic matter fraction in the soil (all in $\mathrm{Mg} \mathrm{C} \mathrm{ha-1).}$ The size of the IOM fraction was set according to the equation given by Falloon et al. (1998a):

$I O M=0.049 \times C_{\text {meas }}^{1.139}$

Following this procedure, the adjusted annual plant addition was determined and redistributed monthly according to typical pattern, as well as the initial C content of the different SOC pools (DPM, RPM, BIO, HUM and IOM) for each province and land use classes combinations. Then, simulations were run for 100 years in order to explore the long-term dynamics of SOC with time for different management scenarios involving changes in the $\mathrm{C}$ inputs to the soils. As SOC dynamics are not linear, simulation runs were also stopped at 20 years for comparison purposes. This reference period has been applied in other studies for 
estimating SOC stock changes (IPCC, 2006; Ogle et al, 2005) and field trials usually capture short term SOC dynamics (<20 years) (Aguilera et al., 2013).

\subsection{Description of scenarios}

Once the baseline SOC content had been established for each province and land uses considered, five main management scenarios were modelled for a 100-year-period using average climatic data (AEMET, 2012) and exploring different strategies for increasing C inputs in the agricultural soils of the study area.

\subsubsection{Baseline scenario (equilibrium)}

For comparison purposes this scenario was used as a baseline in order to assess the effects of the other scenarios on SOC sequestration. Soil organic $\mathrm{C}$ is assumed to have reached equilibrium (>30 years with the same management). Animal manure application rates are considered for each province according to regional manure production and available cropland area.

\subsubsection{Scenario CCR (Cover crops for woody croplands)}

We explored the influence on SOC of a change in the soil management, involving the cultivation of cover crops in woody croplands (i.e. citrus trees, fruit trees, olive groves, vineyards). This measure was selected as it has been reported to protect vulnerable soils from degradation and erosion risks and to provide several benefits for soil structure and fertility (Castro et al., 2008; Gómez et al., 2009; Ramos et al., 2010). Common cover crops suitable in the area of the study are Gramineae or Leguminosae, cultivated in the zone between trees and maintained from autumn until spring to avoid the competition for water with the woody crop. 
Based on Peregrina et al., (2014), barley was selected as suitable cover crop for semi-arid environments. An annual $\mathrm{C}$ input of $1.7 \mathrm{Mg} \mathrm{C} \mathrm{ha}^{-1} \mathrm{yr}^{-1}$ was estimated to be supplied through cover crop residues which were distributed mainly in the months of February to May.

\subsubsection{Scenario M (Manure management: Anaerobic digestion (M-AD) or Composting (M-CO))}

Different management alternatives for animal manure are explored as they are regarded as promising options for climate change mitigation in the agricultural sector.

While in the baseline scenario raw manure is applied to the soil, in this case two strategies for manure treatment are evaluated: anaerobic digestion (M-AD) and composting (M-CO). From the initial amount of available raw manure, the $\mathrm{C}$ and $\mathrm{N}$ flows were simulated through SIMS WASTE according to the selected treatment and manure composition. For both management strategies, the best available technology was assumed. This involves two-stage process and covered storage tank for anaerobic digestion; and weekly turned pile for composting with adjusted moisture and $\mathrm{C}: \mathrm{N}$ ratio. In addition to compost and digestate production and composition (e.g. $\mathrm{Mg}\left(\mathrm{yr}^{-1}\right.$ ), other outputs were obtained from the model such as: gaseous emissions $\left(\mathrm{CO}_{2}, \mathrm{CH}_{4}, \mathrm{NH}_{3}, \mathrm{~N}_{2} \mathrm{O}\right)$ from composting process, and biogas and electricity generated from anaerobic digestion.

The application rates added to the soil range $0.12-1.22 \mathrm{Mg} \mathrm{C} \mathrm{ha}^{-1} \mathrm{yr}^{-1}$ for digestate and 0.091.04 Mg C ha-1 $\mathrm{yr}^{-1}$ for compost. They were estimated according to the annual amounts of digestate $(M-A D)$ or compost $(M-C O)$ obtained from our simulation and the available cropland area for each province (in Mg C ha- $\mathrm{yr}^{-1}$ ). Different labile (DPM), resistant (RPM) and humified (HUM) C inputs from different pools were applied for compost (DPM=0\%, RPM=80\%, HUM $=20 \%$ ) derived from (Peltre et al., 2012) and for digestate (DPM=20\%, RPM=78\%, HUM=2\%) based on own estimations and digestate composition. 


\subsubsection{Scenario UWA (Urban waste)}

The application of urban waste to agricultural cropland is evaluated considering two different flows: compost from municipal solid waste and sewage sludge. Application rates range 0.101.44 Mg C ha-1 $\mathrm{yr}^{-1}$. They were estimated for each province according to urban waste production and available cropland area. Specific $\mathrm{C}$ inputs from different pools were applied for compost (DPM=0\%, RPM=80\%, $\mathrm{HUM}=20 \%$ ) and sewage sludge (DPM=0\%, $\mathrm{RPM}=85 \%$, HUM=15\%) based on Peltre et al (2012).

\subsubsection{Scenario FW (Agri-food by-products: Anaerobic digestion (FW-AD) or Composting (FW-} co))

In combination with the measure considering the urban waste application of scenario UWA, available local by-products from agri-food industries are also considered for biological treatment through anaerobic digestion (FW-AD) or composting (FW-CO). Carbon and N flows were simulated through SIMS WASTE according to the selected treatment and specific food byproducts composition. As a result, compost and digestate production $\left(\mathrm{Mg} \mathrm{C} \mathrm{yr}^{-1}\right)$, were obtained from the model as well as other outputs such as: gaseous emissions $\left(\mathrm{CO}_{2}, \mathrm{CH}_{4}, \mathrm{NH}_{3}\right.$, $\mathrm{N}_{2} \mathrm{O}$ ) from composting process, and biogas and electricity generated from anaerobic digestion. The application rates range $0.02-0.22$ and $0.05-0.28 \mathrm{Mg} \mathrm{C} \mathrm{ha}^{-1} \mathrm{yr}^{-1}$ for food by-products digestate (FW-AD) and compost (FW-CO) respectively. They were estimated according to the annual amounts obtained from simulation and the available cropland area for each province. Different labile (DPM), resistant (RPM) and humified (HUM) C inputs from different pools were applied for compost (DPM=0\%, RPM=80\%, HUM=20\%) derived from Peltre et al (2012) and for digestate (DPM=20\%, RPM=78\%, HUM=2\%) based on own estimations and digestate composition. 


\subsubsection{Scenario MAX (Maximum SOC increase potential (CCR +FW-CO))}

In this scenario, the most promising scenarios increasing $C$ inputs to the soil are selected. In an attempt to evaluate the maximum potential for SOC increase in the study area, the combined effects of cover crops cultivation (CCR), and urban waste and food by-products compost addition to the soil (FW-CO) are explored.

\subsection{Uncertainty analysis}

As the aim of the study was to explore the potential of different strategies to increase SOC stocks, specific attention was paid to evaluate the influence of parameter uncertainty in relation with the additional $\mathrm{C}$ inputs to the soil involved in the study. A MonteCarlo analysis (number of simulations: 1000; normal distribution assumed) was applied to the Scenario MAX which explores the maximum potential for SOC increase by combining cover crops and EOM addition to the soil. A set of uncertainties and probability density functions (PDFs) were adopted for parameters describing the amount $\left(\mathrm{MgC}^{-1}\right)$ and stability (DPM, RPM, HUM) of the additional $\mathrm{C}$ inputs in the model. A thorough description of the methodology used for uncertainty analysis can be found in the Supplementary Material (Table S4).

\section{Results}

The largest effect for a measure introduced in isolation was cover cropping (CCR), which

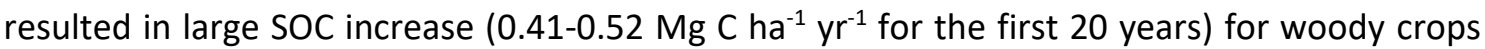
(Table 3). Adding urban waste (UWA) to the baseline, which already includes non-treated manure amendment, increased SOC between $0.08-0.16 \mathrm{Mg} \mathrm{C}^{-1} \mathrm{yr}^{-1}$ for the first 20 years. Scenarios FW-AD and FW-CO, which involved additional C inputs (digested or composted agrifood by-products) to the urban waste resulted in further increase of the SOC stock compared to the baseline ranging $0.10-0.20$ and $0.11-0.21 \mathrm{Mg} \mathrm{ha}^{-1} \mathrm{yr}^{-1}$, respectively (Table 3). Processing 
the available manure from baseline scenarios not seem to significantly change SOC through composting (M-CO), but it resulted in a slight loss of SOC (up to $-0.04 \mathrm{Mg} \mathrm{ha}^{-1} \mathrm{yr}^{-1}$ ) in the first 20 years for the scenarios where manure went through anaerobic digestion (M-AD).

Table 3. Carbon sequestration rates per hectare (in $\mathrm{Mg} \mathrm{ha}^{-1} \mathrm{yr}^{-1}$ ) for the first 20 years for the different management scenarios and land uses

\begin{tabular}{lrlllcccc}
\hline Land use & \multicolumn{1}{l}{$\begin{array}{l}\text { Area } \\
10^{3} \text { ha }\end{array}$} & \multicolumn{7}{c}{$\begin{array}{l}\text { SOC increase } \\
\text { Mg C ha }{ }^{-1} \mathrm{yr}^{-1}\end{array}$} \\
\hline & & CCR & M-AD & M-CO & UWA & FW-AD & FW-CO & MAX \\
\hline Horticulture & 92 & 0.00 & -0.04 & -0.01 & 0.09 & 0.12 & 0.13 & 0.13 \\
Citrus trees & 275 & 0.41 & -0.03 & -0.01 & 0.08 & 0.10 & 0.11 & 0.53 \\
Fruit trees & 429 & 0.41 & -0.04 & -0.01 & 0.09 & 0.11 & 0.12 & 0.54 \\
Olive groves & 705 & 0.52 & -0.03 & -0.02 & 0.07 & 0.12 & 0.12 & 0.64 \\
Vineyards & 171 & 0.52 & -0.06 & -0.02 & 0.16 & 0.20 & 0.21 & 0.74 \\
\hline TOTAL & 1,672 & 0.44 & -0.04 & -0.01 & 0.09 & 0.12 & 0.13 & 0.58 \\
\hline
\end{tabular}

The scenario MAX integrating cover cropping (CCR) with addition of urban waste and composted agri-food by-products (FW-CO) resulted in a range of increased SOC from 0.53 (citrus trees) to 0.74 (vineyards) $\mathrm{Mg} \mathrm{C} \mathrm{ha-1} \mathrm{yr}^{-1}$ (for the first 20 years). Amongst woody crops, vineyards consistently showed the largest potential for SOC accumulation in all scenarios (Table 3).

For horticultural cropping systems, where no cover cropping was used as a measure, adding urban waste amendment (UWA) resulted in a SOC increase of $0.09 \mathrm{Mg} \mathrm{ha}^{-1} \mathrm{yr}^{-1}$ for the first 20 years. Further addition and processing of agri-food by-products increased SOC, for the first 20 years, about $0.12 \mathrm{Mg} \mathrm{ha}^{-1} \mathrm{yr}^{-1}$ and $0.13 \mathrm{Mg} \mathrm{ha}^{-1} \mathrm{yr}^{-1}$ for anaerobic digestion (FW-AD) and composting (FW-CO), respectively (Table 3 ).

As an example and in order to illustrate the evolution in time of SOC accumulation for the different land uses, we utilised results from 3 land uses in Murcia province as an example of 
SOC accumulation ( $\left.\mathrm{Mg} \mathrm{ha}^{-1} \mathrm{yr}^{-1}\right)$ effects in the different scenarios for a 100 years' timeline (Fig 3). Figure 3 shows that the evolution in SOC accumulation is similar in shape but not in magnitude for the 3 land uses analysed. Although the rate of SOC accumulation becomes lower with time for the 3 land uses (about half of the total $C$ sequestration is produced during the first 20 years), this trend is more apparent for the cropping systems that have larger potential for SOC accumulation, i. e. olive groves.
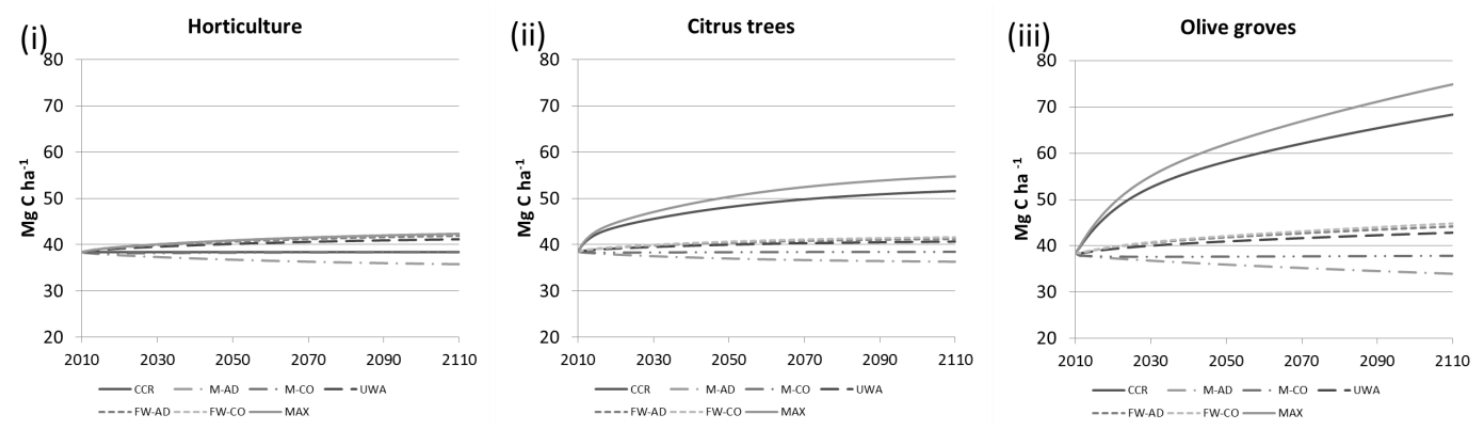

Figure 3. Soil organic carbon (SOC) accumulation (Mg ha-1 $\mathrm{yr}-1$ ) in a 100 years timeline in the $C C R, M-A D, M-C O, U W A, F W-A D, F W-C O, M A X$ scenarios in the Murcia province and for three different land uses: (i) horticulture, (ii) citrus trees and (iii) olive groves.

Table 4 shows total potential SOC changes in 2100 when simulating the different alternative scenarios taking into account the total surface in the study area of each land use type. As expected, the largest increase in SOC accumulation was observed for the scenario where we integrated cover cropping (not applicable for horticultural systems) and composting of urban waste and agri-food industry by-products (MAX), resulting in an accumulation of $40.4 \mathrm{Tg} \mathrm{C}$ of SOC after 100 years, which represents an increase of $60 \%$ in comparison with the baseline scenario.

Land use-wise, the largest potential for SOC increase after 100 years was observed for woody crops; in particular for olive groves $(19.2 \mathrm{Tg} \mathrm{C})$ and fruit trees $(9.3 \mathrm{Tg} \mathrm{C})$, which had both a large 
potential of SOC increase per hectare and a large area coverage in the region (Table 4). For horticultural systems, the scope to increase SOC was lower than $1 \mathrm{Mt}(16 \%)$, which is mainly due to a limited potential per ha of SOC accumulation and the smaller coverage compared with woody crops (Table 4).

Cover cropping (implemented only in woody crops) as a single measure, resulted in almost 30 Tg C of total SOC accumulation after 100 years (Table 4). Adding urban waste (UWA) to the baseline led to SOC accumulation of a total of about $7 \mathrm{Tg} \mathrm{C}$ after 100 years. The largest increase in SOC for the UWA scenario was estimated in vineyards (19\%) and horticultural (11\%) systems (Table 4). Scenarios FW-AD and FW-CO, which involved additional C inputs (digested or composted agri-food by-products) to the urban waste and manure, resulted in further increase of the total SOC stock in the study area of about 9.6 and $10.3 \mathrm{Tg}$ C after 100 years, respectively (Table 4).

Processing the available manure through anaerobic digestion (M-AD) or composting (M-CO) resulted in a small change of SOC compared with the baseline non-treated manured scenario (Table 4). Net GHG emissions, however, if we consider the balance for both the soil stage (i.e. SOC accumulation) and the net GHG emissions from the manure storage and processing together, show a different climate change mitigation potential (Table 5). In table 5, for each province and overall the study area we calculated the relative net GHG emissions gains/loss from composting and anaerobic digestion scenarios compared with the baseline scenario (nonprocessed manure). In order to calculate this balance we considered emissions, avoided emissions and C sinks coming from: (i) GHG emissions from manure storage in the baseline scenario, (ii) GHG emissions avoided through anaerobic digestion process (i.e. generation of alternative energy), (iii) GHG emissions from the composting process and (iv) SOC change from $A D$ and composting scenarios compared with the baseline scenario. In this sense, even though $A D$ is a practice that leads to small SOC losses, if we account for the GHG avoided by the generation of alternative energy through $\mathrm{CH}_{4}$ generation and much lower $\mathrm{GHG}$ emissions 
compared with conventional manure storage, the potential is very large ( $>100 \mathrm{Tg} C$ after 100 years). For manure composting, compared with the baseline scenario without manure treatment, estimated GHG emissions (mainly $\mathrm{CH}_{4}$, data not shown) are smaller and if integrated with potential SOC gains/losses would lead to large GHG emissions savings (about $29 \operatorname{Tg}$ C after 100 years).

Monte Carlo simulation was used to assess the sensitivity of the results to uncertainties in the estimation of $C$ inputs of cover crops and EOMs. Figure 4 shows the range in the change in SOC for the MAX scenario, from 33 to $48 \mathrm{Tg} C$ after 100 years. On average, soils in the study area would had a net gain of $40.0 \mathrm{Tg}$ C (100 years) with a $95 \%$ confidence interval ranging from 35.6 to $45.2 \mathrm{Tg} \mathrm{C}$ (Table 6). Most of this gain would be attributed to woody crops, and especially to olive groves and fruit trees which constitutes a large part of the agricultural surface in the study area.

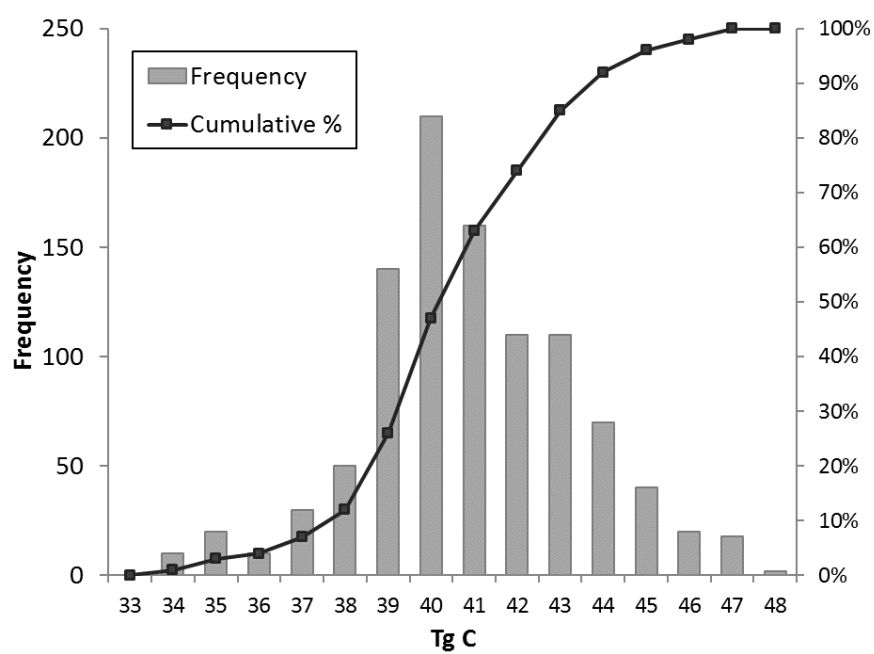

Figure 4. Frequency distribution of Montecarlo simulation of MAX scenario, which combines cover crops and addition of compost to the soil. Data represents changes in soil organic carbon (SOC) in 2100 with respect to the baseline scenario. The figure represents the results of 1000 runs of the RothC model with parameters related to amount and composition (DPM:RPM:HUM) of exogenous organic matter (EOM) randomly drawn from their expected distribution. Data are in groups of of $1 \mathrm{Tg}$, and labels indicate the upper bound of each group (e.g. $48=47.01-48.00$ ) 


\section{Discussion}

This study is intended to provide an estimation of the potential scope for Mediterranean horticulture and intensive orchard to increase SOC through management changes that promote increasing the amount of $\mathrm{C}$ applied to the soil (i.e. via urban waste and agro-industry by-products and cover crop residues). Indirectly some of these practices can also affect agricultural productivity and resilience to climate change and future resource shortage, thus allowing us to assess the potential of these practices to fulfil the objectives of climate-smart agriculture (Lipper et al., 2014; Scherr et al., 2012).

The Mediterranean basin is inherently poor in SOM and is prone to loose SOC via different mechanisms (e.g. erosion) (Hinsinger et al., 2015). Existing literature and modelling carried out in this study provide some basis to say that there are both ample opportunities but also challenges to achieve large realistic SOC accumulation, and indirectly SOM, thus becoming closer to the attributes that climate-smart agriculture requires.

In Mediterranean conditions, modelling studies have concluded that the impact of climate change on SOC changes will depend on the existing cropping systems and management practices (Lugato and Berti, 2008; Álvaro-Fuentes and Paustian, 2011). For example, at the regional level and for the same climate scenario, in NE Spain the Century model predicted SOC gains in arable systems but C losses in orchard systems (Álvaro-Fuentes et al., 2012a).

\subsection{SOC sequestration potential in Spanish Mediterranean horticulture and intensive orchard}

The potential of European agricultural management practices to mitigate climate change in terms of SOC sequestration has been reviewed in different papers (e.g. Freibauer et al., 2004; Smith, 2004) indicating SOC sequestration rates up to $0.70 \mathrm{Mg} \mathrm{Cha-1} \mathrm{yr}^{-1}$. Our results (for 20- 
year average) show that the largest SOC sequestration would be expected with the use of cover crops with sequestration rates between $0.41-0.52 \mathrm{Mg} \mathrm{Cha}^{-1} \mathrm{yr}^{-1}$ during the first 20 years.

The potential for SOC accumulation by cover crops has been widely recognised but rates differ from one study to another. Recently, Poeplau and Don (2015) reviewing the impact of cover crops on SOC sequestration indicated mean sequestration rates of $0.32 \mathrm{MgC} \mathrm{ha}^{-1} \mathrm{yr}^{-1}$, and similar values ( $\left.0.27 \mathrm{Mg} \mathrm{C} \mathrm{ha}^{-1} \mathrm{yr}^{-1}\right)$ were reported by Aguilera et al (2013) in a meta-analysis for the Mediterranean area. These results are lower than the values predicted in our study. The potential for SOC sequestration after the inclusion of cover crops is determined by several factors such as the $\mathrm{C}$ : $\mathrm{N}$ ratio, the lignin content, the amount and quality of root exudates and the root structure and production, together with soil characteristics (Plaza-Bonilla et al., 2015). Other studies have indicated higher SOC sequestration rates than our estimates. For example, González-Sánchez et al. (2012) observed SOC accumulation of $1.54 \mathrm{Mg} \mathrm{C}_{\text {ha-1 }} \mathrm{yr}^{-1}$ for cover crops sowed in-between perennial tree rows, which is in accordance with values observed in field experiments in olive groves by Nieto et al. (2012) for the first years after cover cropping implementation.

In our study, we assumed as the current practice (baseline scenario) for the last decades the regular application of available livestock manures, largely pig slurry and a smaller proportion as farmyard manure (FYM), to agricultural soils. According to this general practice we could assume that SOC stocks are in equilibrium at the beginning of implementing new management scenarios (Powlson et al., 2011). Slurry application, low in C concentration, has not a significant potential to increase SOC directly (Aguilera et al., 2013). In Mediterranean conditions, despite it is generally assumed that the application of slurry does not result in an increase in SOC stocks (Aguilera et al., 2013), under certain dryland conditions, the application of pig slurry could result in an increase in crop yield and, in turn, to the SOC accumulation compared to the application of mineral fertilizers (Plaza-Bonilla et al., 2014). Furthermore, the application of pig slurry may be an effective way to improve soil structure (Plaza-Bonilla et al., 2013), increase 
soil $\mathrm{P}$ and $\mathrm{K}$ levels (Domingo-Olive et al., 2016) and reduce soil nitrous oxide (Vallejo et al., 2006) and ammonia emissions if slurry replaces urea for example (Sanz-Cobeña et al., 2014).

Manure can be processed in order to improve its added value. For example, manure composting is considered as an effective and inexpensive method for reducing the volume of animal manure while producing a stabilized soil fertilizer, free of pathogens and weed seeds (Rynk, 1992). As simulated in this study, composting animal manure did not show much potential to increase SOC stocks when compared to the baseline scenario, which uses nontreated manure. Despite more stabilized forms of $C$ are assumed to be present in compost than in manure (Peltre et al., 2012), the lower $C$ amount added compared with raw manure, due to large $\mathrm{CO}_{2}$ emissions during composting process, offsets the overall $\mathrm{SOC}$ accumulation effect. Another example of processing animal manure is the anaerobic digestion (AD). Through the $A D$ process, the most labile $\mathrm{C}$ forms are degraded into biogas $\left(\mathrm{CH}_{4}\right.$ and $\left.\mathrm{CO}_{2}\right)$ resulting in the reduction of the potential of digestate to increase SOC levels. According to SIMS $\mathrm{S}_{\text {waste }}$ (Pardo et al., 2013; Pardo et al., 2017) the AD process would involve among $32 \%$ to $42 \%$ of $C$ in manure converted to biogas. In contrast to composting process, the remaining $\mathrm{C}$ in digestate does not involve higher proportions of stabilized organic matter forms. Therefore, the decrease on the amount of $\mathrm{C}$ input to the soil due to biogas production is reflected on SOC losses with time.

For both scenarios, although the estimated annual SOC accumulation in response to the application of composted or digested manure is negligible or slightly negative, large GHG offsets are expected by reducing GHG emissions from baseline manure storage (Pardo et al., 2015 ) or through the generation of green energy ( $A D$ scenario). Consequently, $A D$ and composting would have a potential for total GHG emissions reductions of 4.3 and $1.1 \mathrm{Tg} \mathrm{CO}_{2} \mathrm{eq}$

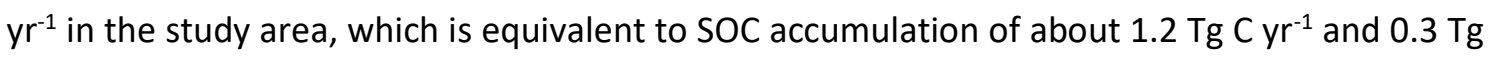
$\mathrm{C} \mathrm{yr}^{-1}$ respectively, averaged during 100-year simulation for all the area considered in the study. The relative importance of this GHG reduction is significant considering that these 
values would represent about $11 \%$ and 3\% of total agricultural emissions in Spain in 2014 (UNFCCC, 2014) for anaerobic digestion and composting, respectively.

Application of urban waste (UWA) through municipal compost and sewage sludge addition across the study area would lead to $7.2 \mathrm{Tg} \mathrm{C}\left(0.04 \mathrm{Mg} \mathrm{C} \mathrm{ha}^{-1} \mathrm{yr}^{-1}\right)$ accumulated after 100 years. For the first 20 years, the average annual SOC accumulation estimated is $0.09 \mathrm{Mg} \mathrm{C} \mathrm{ha-1} \mathrm{yr}^{-1}$ (range 0.04-0.61 Mg C ha-1 $\mathrm{yr}^{-1}$ ). Although our average results are lower than the values estimated for compost amendment by Mondini et al. (2012) in Italy (0.29 $\left.\mathrm{MgC} \mathrm{ha}^{-1} \mathrm{yr}^{-1}\right)$ and by Freibauer et al. (2004) in European agricultural soils (0.40 Mg C ha-1 $\left.\mathrm{yr}^{-1}\right)$, value ranges are within the range of these studies. The disparity of values among studies could be attributed to the difference in methodological approaches. Also, the lower values obtained in our simulation can be attributed to the annual application rates assumed, with an average value of $0.26 \mathrm{Mg} \mathrm{C}$ $\mathrm{ha}^{-1} \mathrm{yr}^{-1}$, which contrasts with the addition rates considered in other studies, about 1-2 Mg C ha ${ }^{-1} \mathrm{yr}^{-1}$. In our study, the availability and applicable rate of urban waste varies significantly among regions (range 0.1- 1.4 Mg C ha $\mathrm{Mr}^{-1}$ ) as it is influenced by population density and availability of cropland area. Thus, in highly populated areas where more urban waste is available, estimated application rates were higher $\left(>1 \mathrm{MgC} \mathrm{ha-1} \mathrm{yr}^{-1}\right)$, and the annual SOC

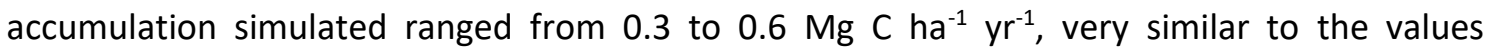
reported in the above mentioned studies.

Using the available agroindustry by-products for SOC stocks accumulation provides opportunities for GHG mitigation as it has been shown in our modelling exercise. Estimated annual SOC accumulation in response to the application of composted or digested

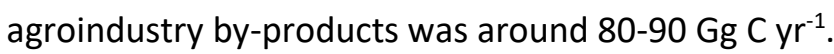

The model simulation indicated that SOC accumulation was significantly enhanced $(>50 \%$ in 100 years) when different management practices were combined although the overall effect would be smaller than the addition of their single effects, which is in agreement with the 
findings of Del Prado et al. (2010). Woody crops, in particular, could have a very high potential for SOC accumulation as cover crops can be combined with the application of agroindustry byproducts, such as olive mill wastes and urban waste. Moreover, although not simulated in this study mulching of pruning residues and non-tillage practices could further increase SOC accumulation (e.g. 0.5-0.6 Mg C ha-1 $\mathrm{yr}^{-1}$ : Nieto et al., 2010) and help increase crop yield (e.g. Montanaro et al., 2010).

Among land uses, the greatest SOC sequestration rate was found in woody crops with the use of cover crops (either as a single practice or in combination with other practices). In Mediterranean areas, woody crops are within the most important cropping systems occupying a large proportion of the territory. For example, in the Mediterranean basin, only olive groves occupy around 9.5 M ha (Nieto et al., 2012). In Spain, natural vegetation covers are extensively used in olive production systems in Andalusia where olive groves are frequently cultivated in steep slopes, but in most of the cases this practice involves a poor soil covering of weeds which are left to grow each year (Nieto et al., 2010; MAGRAMA, 2013). The increase in SOC levels after the adoption of cover crops in woody crops have also been observed by other studies performed in Mediterranean areas (Castro et al., 2008; Nieto et al., 2012; García-Franco et al., 2015). Furthermore, in woody systems, cover crops contribute to other ecosystems services such as erosion control (Gomez et al., 2009; Almagro et al., 2016), soil fertility (Hernández et al., 2005) and soil physical properties (Peregrina et al., 2010).

Management of local carbon through the implementation of smart-agriculture practices (e.g., intercropping with groundcover species, mulching) is expected to reduce erosion as compared to conventional tillage or soil kept bare through herbicides. In fact, a reduction in C lost by erosion of about $30-55 \%$ when conservation practices are applied have been reported by several authors under perennial woody crops such as olive groves, vineyards or almond orchards (Castro et al., 2008; Almagro et al 2014). Despite these benefits, sowing cover crops 
still accounts for a minimal share $(>1 \%)$ of the national total surface of woody crops in Spain (MAGRAMA, 2013).

\subsection{Barriers and opportunities}

Despite the remarkable potential for SOC sequestration of the agricultural soils in Mediterranean areas, mainly due to their low SOC content, several limitations also exist. After the adoption of a determined management practice, the increase in SOC content is a finite process (Powlson et al., 2011). The duration of the $C$ accrual process depends on several factors, such as the practice in question, climate, soil properties and the previous management history. For example, in semiarid areas of Spain, soils under no-tillage (NT) stop sequestering organic C after 12 years (Hernanz et al., 2009; Álvaro-Fuentes et al., 2014). Likewise, it was observed that, during the time in which soils under NT sequestered $\mathrm{C}$, the rate at which they sequestered varied over years. In particular, the maximum sequestration rates occur 5 years after the change in soil management (Álvaro-Fuentes et al., 2014).

Although the use of agri-food by-products shows to have potential to increase SOC when applied as soil amendment, questions may arise on the net transfer of $\mathrm{C}$ between the soil and the atmosphere as it depends on the alternative fate of the by-product (Powlson et al., 2011). For example, avoiding food-competing feedstuff in livestock diet, i.e. feeding livestock with byproducts from food production and grass have been suggested as a strategy that could provide sufficient food in the future (Schader et al., 2015). Organic by-products could have alternative uses (e.g. animal feed, bioenergy, soil amendment), with different implications for SOC stocks and GHG emissions, which may strongly rely on by-product composition. Holistic approaches combining farm models and life-cycle assessment have been recommended for a more complete overview of such complex scenarios (Styles et al., 2014; Pardo et al., 2017). Besides, local context and potential trade-offs from non-GHG issues may play an important role in the decision-making process towards a circular economy (Greyson, 2007). 
The utilisation of urban waste as a soil amendment, mainly after adequate composting treatment, is one of the most adequate valorisation alternatives, but it can also result in several constraints that may limit its agronomic applicability. The potential presence of chemical (heavy metals, PAHs, PCBs, etc.) and biological pollutants (pathogens) can reduce their applicability due to the environmental and health risks (Cesaro et al., 2015), aspects considered in the current European legislations and guidelines related to waste management and soil protection $(E C, 2008)$. In addition, the tendency to develop collective treatment plants could involve additional costs related to the transport to cropland areas.

Future-wise improvement of current mechanical-biological treatments together with the implementation of source separation and separate collection of the organic fraction of municipal waste could play a crucial role in the stability and agronomic quality of these urban waste streams, thus promoting their application. Furthermore, although not explored in this study, there is also great future potential to use as soil amendments other organic materials that are currently and frequently burned in the field (pruning residues and straw) or that poses an environmental risk (e.g. olive mill and other agro-industrial wastes) unless careful separation or pre-treatment at source is carried out.

\subsection{Sources of uncertainty}

Results from SOC simulations involve some uncertainties which can be associated with different sources such as the methodology applied, the reliability of the input data or the model of SOC turnover (RothC) applied. In our study, an important limitation could be the hypothetical assumptions taken on the approach used to initialize and run the model. Initial SOC pool distributions are assumed to be at equilibrium/steady state with the current land-use and climatic conditions. Although this approach has been commonly applied the actual soils 
may not be at equilibrium due to changes in land-use and management practices, resulting in biases in the SOC estimations (Wutzler \& Reichstein, 2007).

Simulation of management practices for the different land-use classes may also result in another source of uncertainty. As it was not feasible to model the different combinations of agricultural practices with regards to irrigation, manure application or plant residues management, the most common practices for each cropping system in each province were assumed according to MAGRAMA (2013). Furthermore, in order to simplify simulations average data were used to describe soil characteristics (SOC, \%Clay) and climatic conditions (temperature, precipitation, evapotranspiration) for each province. Although this could represent most of the area studied, local variations may exist.

Uncertainty on the estimations related to the amount and stability of additional C inputs, such as EOMs and cover crops, could be of particular importance, determining the potential of the analysed measures for $\mathrm{C}$ storage in the study area. In order to quantify this uncertainty, a Montecarlo approach was applied for the estimated change in SOC (100 years) in the MAX scenario, which explores the maximum potential for SOC increase by combining cover crops and EOMs addition to the soil. The mean obtained was $40.0 \mathrm{Tg} \mathrm{C}$, very similar to the value using the default parameters ( $40.4 \mathrm{Tg} \mathrm{C}$ ), with a 95\% confidence interval ranging from 35.6 to 45.2 Tg C.

While they must be taken with caution, results from Montecarlo analysis seem to confirm that Mediterranean SOC stocks could be increased if certain strategies are followed. It is undeniable that there are large uncertainties associated to both the activity data used and the parameterization of the model. Despite that, the results from this study could be interpreted as a valuable indicator of the potential value of certain agricultural practices to restore and/or increase the SOC lost due to years of conventional management in these Mediterranean agroecosystems. 


\subsection{Limitations of the SOC estimations}

The dynamic model of SOC turnover used in this study (RothC) involves some limitations. For example, it does not take into account the effects of soil erosion, which is an important process influencing SOC dynamics and with major implications for GHG mitigation and adaptation strategies (Chappell et al., 2015). Erosion would be especially relevant in these Mediterranean environments where high intensity-low frequency rainfall events are responsible for the main part of soil erosion. For example, in orchard trees under conventional management (mainly olives and almonds) a wide range of erosion rates, some very high, have been reported (range 0.05- 19.4 Mg C ha-1 $\mathrm{yr}^{-1}$ ) (Francia Martínez et al., 2006; Martínez-Mena et al., 2008; Gómez et al., 2009). Currently, just a few SOC models account for C fluxes through erosion and run off, and the need to include these processes on most widely used SOC models (e.g. RothC) have been identified (Senapati et al., 2014; Sanderman et al., 2013). Nevertheless, unless these type of models are simplified, the complexity associated to their structure and input data requirements may in fact be a limitation for regional studies.

RothC does not consider the effect of different tillage management systems. Tillage may in fact have an important effect on SOC and soil microbial dynamics (Álvaro-Fuentes et al., 2013). The use of specific agricultural practices for the local management of soil $\mathrm{C}$, such as the reduction in the tillage intensity, seeding an incorporation of cover crops, mulching with crop residues, etc., improves immediately soil conditions, reflected in a rapid stimulation of the soil microbiota, accompanied by a significant increase in the macroaggregates formation. Inside these macroaggregates, the strong chemical bonding between organic matter and mineral soil particles led to stable microaggregates formation leading to an increase in the $\mathrm{C}$ sequestration potential (due to the less susceptibility of the $\mathrm{OC}$ to mineralization).

Other limitations have been identified in relation with direct estimations derived from soil sampling measurements after a change in soil management, especially if the soil depth is not considered. Shallow soil sampling may result in wrong conclusions (Vandenbygaart et al., 2011) 
since a small percentage of the total $C$ stock accumulates at the soil surface. In a study in the Murcia province, it was calculated that $65 \%$ of the total $\mathrm{C}$ accumulated in forest and cropland soils was below $20 \mathrm{~cm}$ (Albaladejo et al., 2013). Furthermore, C stored in deeper layers has been observed to be more stable (Jobbagy and Jackson, 2000). Thus, the minimum soil depth will depend on the management practice adopted and in the root depth and distribution of the crop (Baker et al., 2007). The soil sampling should be able to capture the most part of the rooting depth due to the contribution of the root system to SOC sequestration and turnover (Gale et al., 2000; Rasse et al., 2005). Therefore, to determine the potential of a certain management practice to sequester SOC some precaution should be taken in order to avoid the misinterpretation of the results found.

\section{Conclusions}

Soil organic $\mathrm{C}$ levels are low in the Mediterranean agricultural systems. In this study we found that there is large scope to enhance SOC stocks in orchards and horticultural intensive systems $(>50 \%)$ through management practices increasing $C$ inputs. Sowing cover crops in orchards systems showed the largest SOC accumulation potential. Whilst this practice is currently not widely used in the area, it could also provide other additional benefits such as soil erosion protection and water holding capacity, which are of paramount importance to the Mediterranean conditions.

Application to the soil of EOM such as compost from urban waste or agri-food by-products is another effective way to enhance SOC stocks, but its overall potential is hindered by its regional availability and the potential presence of chemical and biological pollutants.

Organic waste streams may have alternative uses with different implications for SOC stocks but also for GHG emissions. For example, anaerobic digestion, which does not result in SOC accumulation after digestate is applied to the soil, can provide additional benefits for net 
climate change mitigation via bioenergy production. Coupling models and life-cycle assessment methodologies can provide a more complete picture of each particular issue.

\section{Acknowledgments}

The authors would like to thank the Spanish National R+D+i Plan (AGL2012-37815-C05-04; AGL2013-41612-R), DEFRA (AC0122), Project 19350/PI/14 and Murcia Regional Government (SENECA Foundation).BC3 is sponsored by the Basque Government. This paper has been produced within the context of the REMEDIA network http://redremedia.wordpress.com/

\section{References}

Adams, R. C., MacLean, F. S., Dixon, J. K., Bennett, F. M., Martin, G. I., Lough, R. C., 1951. The utilization of organic wastes in N.Z.: Second interim report of the interdepartmental committee. New Zealand Engineering (November 15, 1951):396-424.

AEMET. Agencia Estatal de Meteorología, 2012. Guía resumida del clima en España (in Spanish).

Aguilera, E., Lassaletta, L., Gattinger, A., Gimeno, B.S., 2013. Managing soil carbon for climate change mitigation and adaptation in Mediterranean cropping systems: A meta-analysis. Agric. Ecosyst. Environ. 168, 25-36.

Albaladejo, J., Ortiz, R., Garcia-Franco, N., Navarro, A.R., Almagro, M., Pintado, J.G., Martínez-Mena, M., 2013. Land use and climate change impacts on soil organic carbon stocks in semi-arid Spain. J. Soils Sediments 13, 265-277.

Alburquerque, J., Gonzálvez, J., García, D., Cegarra, J., 2004. Agrochemical characterisation of “alperujo”, a solid by-product of the two-phase centrifugation method for olive oil extraction. Bioresour. Technol. 91, 195-200.

Allen, R.G., Pereira, L. S., Raes, D., 1998. FAO Irrigation and drainage paper No 56. Guidelines for computing crop water requirements - Crop evapotranspiration.

Almagro, M., de Vente, J., Boix-Fayos, C., García-Franco, N., Melgares de Aguilar, J., González, D., SoléBenet, A., Martínez-Mena, M., 2016. Sustainable land management practices as providers of several ecosystem services under rainfed Mediterranean agroecosystems. Mitig. Adapt. Strateg. Glob. Chang. 21, 1029-1043.

Almagro, M., López, J., Boix-Fayos, C., Albaladejo, J., Martínez-Mena, M., 2010. Belowground carbon allocation patterns in a dry Mediterranean ecosystem: A comparison of two models. Soil Biol. Biochem. 42, 1549-1557. 
Almagro, M., Martínez-Mena, M., 2014. Litter decomposition rates of green manure as affected by soil erosion, transport and deposition processes, and the implications for the soil carbon balance of a rainfed olive grove under a dry Mediterranean climate. Agric. Ecosyst. Environ. 196, 167-177.

Álvaro-Fuentes, J., Easter, M., Paustian, K., 2012a. Climate change effects on organic carbon storage in agricultural soils of northeastern Spain. Agric. Ecosyst. Environ. 155, 87-94.

Álvaro-Fuentes, J., López, M. V., Cantero-Martinez, C., Arrúe, J.L., 2008. Tillage Effects on Soil Organic Carbon Fractions in Mediterranean Dryland Agroecosystems. Soil Sci. Soc. Am. J. 72, 541.

Álvaro-Fuentes, J., Morell, F.J., Madejón, E., Lampurlanés, J., Arrúe, J.L., Cantero-Martínez, C., 2013. Soil biochemical properties in a semiarid Mediterranean agroecosystem as affected by long-term tillage and $\mathrm{N}$ fertilization. Soil Tillage Res. 129, 69-74.

Álvaro-Fuentes, J., Morell, F.J., Plaza-Bonilla, D., Arrúe, J.L., Cantero-Martínez, C., 2012b. Modelling tillage and nitrogen fertilization effects on soil organic carbon dynamics. Soil Tillage Res. 120, 32-39.

Álvaro-Fuentes, J., Paustian, K., 2011. Potential soil carbon sequestration in a semiarid Mediterranean agroecosystem under climate change: Quantifying management and climate effects. Plant Soil $338,261-272$.

Álvaro-Fuentes, J., Plaza-Bonilla, D., Arrúe, J.L., Lampurlanés, J., Cantero-Martínez, C., 2014. Soil organic carbon storage in a no-tillage chronosequence under Mediterranean conditions. Plant Soil 376, 31-41.

Baker, J.M., Ochsner, T.E., Venterea, R.T., Griffis, T.J., 2007. Tillage and soil carbon sequestration-What do we really know? Agric. Ecosyst. Environ. 118, 1-5.

Balesdent, J., Mariotti, A., Boisgontier, D., 1990. Effect of tillage on soil organic carbon mineralization estimated from $13 \mathrm{C}$ abundance in maize fields. Journal of Soil Science, 41(4), 587-596.

Boix-Fayos, C., Martínez-Mena, M., Calvo-Cases, A., Castillo, V., Albaladejo, J., 2005. Concise review of interrill erosion studies in SE Spain (Alicante and Murcia): erosion rates and progress of knowledge from the 1980s. L. Degrad. Dev. 16, 517-528.

Bustamante, M. A, Moral, R., Paredes, C., Pérez-Espinosa, A, Moreno-Caselles, J., Pérez-Murcia, M.D., 2008. Agrochemical characterisation of the solid by-products and residues from the winery and distillery industry. Waste Manag. 28, 372-80.

Castro, J., Fernández-Ondoño, E., Rodríguez, C., Lallena, A.M., Sierra, M., Aguilar, J., 2008. Effects of different olive-grove management systems on the organic carbon and nitrogen content of the soil in Jaén (Spain). Soil Tillage Res. 98, 56-67.

Cesaro, A., Belgiorno, V., Guida, M., 2015. Compost from organic solid waste: Quality assessment and European regulations for its sustainable use. Resour. Conserv. Recycl. 94, 72-79.

Chappell, A., Baldock, J., Sanderman, J., 2015. The global significance of omitting soil erosion from soil organic carbon cycling models. Nat. Clim. Chang. 1-5.

Coleman, K., \& Jenkinson, D. S., 1996. RothC-26.3-A Model for the turnover of carbon in soil. In Evaluation of soil organic matter models (pp. 237-246). Springer Berlin Heidelberg. 
Coleman, K., Jenkinson, D.S., Crocker, G.J., Grace, P.R., Klír, J., Körschens, M., Poulton, P.R., Richter, D.D., 1997. Simulating trends in soil organic carbon in long-term experiments using RothC-26.3. Geoderma 81, 29-44.

Del Prado A., Alvaro-Fuentes J., Arriaga H., Báez D., Bernal M.P., Cantero C., Estellés F., Merino P., Moral R., Pardo G., Salcedo G., Salva C., Sanz-Cobeña A . 2013. GHG emissions associated with manure management from livestock systems in a Mediterranean country. A case study: Spain. in: Proceeding of the 15th RAMIRAN International Conference. INRA - Université de Versailles StQuentin-en-Yvellines, Versailles. http://bit.ly/2cGo34x

Del Prado., A, Chadwick, D., Cardenas, L., Misselbrook, T., Scholefield, D., Merino, P., 2010. Exploring systems responses to mitigation of GHG in UK dairy farms. Agric. Ecosyst. Environ. 136, 318-32.

Domingo-Olivé, F., Bosch-Serra, À.D., Yagüe, M.R., Poch, R.M., Boixadera, J., 2016. Long term application of dairy cattle manure and pig slurry to winter cereals improves soil quality. Nutr. Cycl. Agroecosystems 104, 39-51.

EC. European Commission, 2008. Directive 2008/98/EC of the European Parliament and of the Council of 19 November 2008 on waste and repealing certain Directives. Official Journal of the European Union L, 312(3).

Eurostat 2015. Statistics Explained (http://ec.europa.eu/eurostat/statistics-explained/). (accessed February 2016).

Falloon, P., Smith, P., 2002. Simulating SOC changes in long-term experiments with RothC and CENTURY: model evaluation for a regional scale application. Soil Use Manag. 18, 101-111.

Falloon, P., Smith, P., Coleman, K., Marshall, S., 1998a. Estimating the size of the inert organic matter pool from total soil organic carbon content for use in the Rothamsted carbon model. Soil Biol. Biochem. 30, 1207-1211.

Falloon, P.D., Smith, P., Smith, J.U., Szabó, J., Coleman, K., Marshall, S., 1998b. Regional estimates of carbon sequestration potential: linking the Rothamsted Carbon Model to GIS databases. Biol. Fertil. Soils 27, 236-241.

Farina, R., Seddaiu, G., Orsini, R., Steglich, E., Roggero, P.P., Francaviglia, R., 2011. Soil carbon dynamics and crop productivity as influenced by climate change in a rainfed cereal system under contrasting tillage using EPIC. Soil Tillage Res. 112, 36-46.

Federici, F., Fava, F., Kalogerakis, N., Mantzavinos, D., 2009. Valorisation of agro-industrial by-products, effluents and waste: concept, opportunities and the case of olive mill wastewaters. J. Chem. Technol. Biotechnol. 84, 895-900.

Fernández-Zamudio, M.A., De Miguel, M.D., 2006. Sustainable management for woody crops in Mediterranean dry-lands. Spanish J. Agric. Res. 4, 111-123.

Francaviglia, R., Coleman, K., Whitmore, A.P., Doro, L., Urracci, G., Rubino, M., Ledda, L., 2012. Changes in soil organic carbon and climate change - Application of the RothC model in agro-silvopastoral Mediterranean systems. Agric. Syst. 112, 48-54. 
Francia Martínez, J.R., Durán Zuazo, V.H., Martínez Raya, A., 2006. Environmental impact from mountainous olive orchards under different soil-management systems (SE Spain). Sci. Total Environ. 358, 46-60.

Freibauer, A., Rounsevell, M.D.A., Smith, P., Verhagen, J., 2004. Carbon sequestration in the agricultural soils of Europe. Geoderma. 127, 1-23.

Gale, W.J., Cambardella, C.A., Bailey, T.B., 2000. Root-derived carbon and the formation and stabilization of aggregates. Soil Sci. Soc. Am. J. 64, 201-207.

Garcia-Franco, N., Albaladejo, J., Almagro, M., Martínez-Mena, M., 2015. Beneficial effects of reduced tillage and green manure on soil aggregation and stabilization of organic carbon in a Mediterranean agroecosystem. Soil Tillage Res. 153, 66-75.

García-Ruiz, J.M., 2010. The effects of land uses on soil erosion in Spain: A review. CATENA 81, 1-11.

Gómez, J.A., Sobrinho, T., Giraldez, J., Fereres, E., 2009. Soil management effects on runoff, erosion and soil properties in an olive grove of Southern Spain. Soil Tillage Res. 102, 5-13.

González-Sánchez, E.J., Ordóñez-Fernández, R., Carbonell-Bojollo, R., Veroz-González, O., Gil-Ribes, J.A., 2012. Meta-analysis on atmospheric carbon capture in Spain through the use of conservation agriculture. Soil Tillage Res. 122, 52-60.

Greyson, J., 2007. An economic instrument for zero waste, economic growth and sustainability. J. Clean. Prod. 15, 1382-1390.

Grigg, D. B., 1974. The agricultural systems of the world: An evolutionary approach (Vol. 5). Cambridge University Press.

Hernández, A.J., Lacasta, C., Pastor, J., 2005. Effects of different management practices on soil conservation and soil water in a rainfed olive orchard. Agric. Water Manag. 77, 232-248.

Hernanz, J.L., Sánchez-Girón, V., Navarrete, L., 2009. Soil carbon sequestration and stratification in a cereal/leguminous crop rotation with three tillage systems in semiarid conditions. Agric. Ecosyst. Environ. 133, 114-122.

Hinsinger, P., Anastasiou, D., Aran, M., Balesdent, J., Basch, G., Biró, B., Mourão, I., Costantini, E., Dell'Abate, M.T., Follain, S., Gómez, H., Konsten, C., Lloveras, J., Marques, F., Martínez, C. C., Mavridis, A., Neeteson, J., Perdigão, A., Sarno, G., Theocharopoulos, S., Blanco, J., Ambar, M., Dietz, S., 2015. Soil organic matter content in Mediterranean regions. Final Report EIP-Agri Focus Group. March 2015. http://ec.europa.eu/eip/agriculture/sites/agri-eip/files/eipagri fg soil organic matter final report 2015 en $0 . p d f$

http://www.probiogas.es/ (accessed February, 2016).

IPCC, 2006. IPCC Guidelines for National Greenhouse Gas Inventories. Prepared by the National Greenhouse Gas Inventories Programme. IGES, Japan.

IPCC, 2013. Climate Change 2013: The Physical Science Basis. Contribution of Working Group I to the Fifth Assessment Report of the Intergovernmental Panel on Climate Change. In: Stocker, T.F., Qin, D., Plattner, G.-K., Tignor, M. , Allen, S.K., Boschung, J., Nauels, A. Xia, Y., Bex, V., Midgley, P.M. (Ed), Cambridge University Press, Cambridge, UK and New York, USA, 1535 pp. 
Jenkinson, D.S., Harris, H.C., Ryan, J., McNeill, A.M., Pilbeam, C.J., Coleman, K., 1999. Organic matter turnover in a calcareous clay soil from Syria under a two-course cereal rotation. Soil Biol. Biochem. 31, 687-693.

Jobbágy, E.G., Jackson, R.B., 2000. The vertical distribution of soil organic carbon and its relation to climate and vegetation. Ecol. Appl. 10, 423-436.

Johnston, A.E., Poulton, P.R., Coleman, K., 2009. Soil Organic Matter: Its Importance in Sustainable Agriculture and Carbon Dioxide Fluxes. Adv. Agron. 101, 1-57.

Kushnir, Y., 2015. Mediterranean climate future: an insightful look into the Basin's precipitation response to greenhouse gas forcing. Environ. Res. Lett. 10, 104012.

Lal, R., 2004. Soil carbon sequestration to mitigate climate change. Geoderma 123, 1-22.

Lipper, L., Thornton, P., Campbell, B.M., Baedeker, T., Braimoh, A., Bwalya, M., Caron, P., Cattaneo, A., Garrity, D., Henry, K., Hottle, R., Jackson, L., Jarvis, A., Kossam, F., Mann, W., McCarthy, N., Meybeck, A., Neufeldt, H., Remington, T., Sen, P.T., Sessa, R., Shula, R., Tibu, A., Torquebiau, E.F., 2014. Climate-smart agriculture for food security. Nat. Clim. Chang. 4, 1068-1072.

Liu, D.L., Chan, K.Y., Conyers, M.K., 2009. Simulation of soil organic carbon under different tillage and stubble management practices using the Rothamsted carbon model. Soil Tillage Res. 104, 6573.

Ludwig, R., Roson, R., 2016. Climate change, water and security in the Mediterranean: Introduction to the special issue. Sci. Total Environ., 543(Pt B), 847-850.

Lugato, E., Berti, A., 2008. Potential carbon sequestration in a cultivated soil under different climate change scenarios: A modelling approach for evaluating promising management practices in north-east Italy. Agric. Ecosyst. Environ. 128, 97-103.

Mancinelli, R., Marinari, S., Di Felice, V., Savin, M.C., Campiglia, E., 2013. Soil property, $\mathrm{CO}_{2}$ emission and aridity index as agroecological indicators to assess the mineralization of cover crop green manure in a Mediterranean environment. Ecol. Indicators 34, 31-40.

Marmo, L., Feix, I., Bourmeau, E., Amlinger, F., Bannick, C. G., De Neve, S., Leifert, I. Morris, R., Cruz, A., Ruck, F., Sieber, S., Tittarelli, F., 2004. Exogenous organic matter. Thematic Strategy for Soil Protection, 395-438.

Martínez-Mena, M., López, J., Almagro, M., Boix-Fayos, C., Albaladejo, J., 2008. Effect of water erosion and cultivation on the soil carbon stock in a semiarid area of South-East Spain. Soil Tillage Res. 99, 119-129.

MARM, 2009 Ministerio de Medio Ambiente y medio Rural y Marino. Anuario de Estadística (in Spanish). MAGRAMA, 2011 Ministerio de Agricultura, Alimentación y Medio Ambiente. Anuario de Estadística (in Spanish).

MAGRAMA, 2013 Ministerio de Agricultura Alimentación y Medio Ambiente. Encuesta sobre superficies y rendimientos de cultivos. Resultados nacionales y autonómicos (in Spanish).

MAGRAMA, 2015 Ministerio de Agricultura Alimentación y Medio Ambiente. Inventario nacional de erosión de suelos (in Spanish). 
Mondini, C., Coleman, K., Whitmore, A. P., 2012. Spatially explicit modelling of changes in soil organic C in agricultural soils in Italy, 2001-2100: Potential for compost amendment. Agric. Ecosyst. Environ. 153, 24-32.

Montanaro, G., Celano, G., Dichio, B., Xiloyannis, C., 2010. Effects of soil-protecting agricultural practices on soil organic carbon and productivity in fruit tree orchards. Land Degrad. Dev. 21, 132-138.

Morales, A.B., Bustamante, M.A., Marhuenda-Egea, F.C., Moral, R., Ros, M., Pascual, J.A., 2016. Agrifood sludge management using different co-composting strategies: study of the added value of the composts obtained. J. Clean. Prod. 121, 186-197.

Nieto, O.M., Castro, J., Fernández, E., Smith, P., 2010. Simulation of soil organic carbon stocks in a Mediterranean olive grove under different soil-management systems using the RothC model. Soil Use Manag. 26, 118-125.

Nieto, O.M., Castro, J., Fernández-Ondoño, E., 2012. Conventional tillage versus cover crops in relation to carbon fixation in Mediterranean olive cultivation. Plant. Soil. 365, 321-335.

Ogle, S.M., Breidt, F.J., Paustian, K., 2005. Agricultural management impacts on soil organic carbon storage under moist and dry climatic conditions of temperate and tropical regions. Biogeochemistry 72, 87-121.

Ozturk, T., Ceber, Z.P., Türkeş, M., Kurnaz, M.L., 2015. Projections of climate change in the Mediterranean Basin by using downscaled global climate model outputs. Int. J. Climatol. 35, 4276-4292.

Pardo, G., Martin-Garcia, I., Arco, A., Yañez-Ruiz, D.R., Moral, R., del Prado, A., 2016. Greenhouse-gas mitigation potential of agro-industrial by-products in the diet of dairy goats in Spain: a life-cycle perspective. Anim. Prod. Sci. 56, 646-654.

Pardo, G., Moral, R., Aguilera, E., del Prado, A., 2015. Gaseous emissions from management of solid waste: a systematic review. Glob. Change Biol. 21, 1313-1327.

Pardo, G., Moral, R., del Prado, A., 2017. SIMSwASTE-AD - A modelling framework for the environmental assessment of agricultural waste management strategies: Anaerobic digestion. Sci. Total Environ. 574, 806-817.

Pardo, G., Moral, R., del Prado, A., 2013. Modelling management options of organic waste for the evaluation of synergies and trade-offs between climate change mitigation and ecosystem services, in: Proceeding of the 15th RAMIRAN International Conference. INRA - Université de Versailles St-Quentin-en-Yvellines, Versailles. http://bit.ly/2cNwaLv (accessed 27.09.16)

Peltre, C., Christensen, B.T., Dragon, S., Icard, C., Kätterer, T., Houot, S., 2012. RothC simulation of carbon accumulation in soil after repeated application of widely different organic amendments. Soil Biol. Biochem. 52, 49-60.

Peregrina, F., Larrieta, C., Ibáñez, S., García-Escudero, E., 2010. Labile organic matter, aggregates, and stratification ratios in a semiarid vineyard with cover crops. Soil Sci. Soc. Am. J. 74, 2120-2130. 
Peregrina, F., Pérez-Álvarez, E.P., García-Escudero, E., 2014. The short term influence of aboveground biomass cover crops on $\mathrm{C}$ sequestration and b-glucosidase in a vineyard ground under semiarid conditions. Spanish J. Agric. Res. 12, 1000-1007.

Plaza-Bonilla, D., Álvaro-Fuentes, J., Cantero-Martínez, C., 2013. Soil aggregate stability as affected by fertilization type under semiarid no-tillage conditions. Soil Sci. Soc. Am. J. 77, 284-292.

Plaza-Bonilla, D., Arrúe, J.L., Cantero-Martínez, C., Fanlo, R., Iglesias, A., Álvaro-Fuentes, J., 2015. Carbon management in dryland agricultural systems. A review. Agron. Sustain. Dev. 35, 1319-1334.

Plaza-Bonilla, D., Cantero-Martínez, C., Bareche, J., Arrúe, J.L., Álvaro-Fuentes, J., 2014. Soil carbon dioxide and methane fluxes as affected by tillage and $\mathrm{N}$ fertilization in dryland conditions. Plant Soil 381, 111-130.

Poeplau, C., Don, A., 2015. Carbon sequestration in agricultural soils via cultivation of cover crops - A meta-analysis. Agric. Ecosyst. Environ. 200, 33-41.

Post, W.M., Emanuel, W.R., Zinke, P.J., Stangenberger, A.G., 1982. Soil carbon pools and world life zones. Nature 298, 156-159.

Powlson, D.S., Whitmore, A.P., Goulding, K.W.T., 2011. Soil carbon sequestration to mitigate climate change: a critical re-examination to identify the true and the false. Eur. J. Soil Sci. 62, 42-55.

Ramos, M.E., Benítez, E., García, P.A., Robles, A.B., 2010. Cover crops under different managements vs. frequent tillage in almond orchards in semiarid conditions: Effects on soil quality. Appl. Soil Ecol. 44, 6-14.

Rasse, D.P., Rumpel, C., Dignac, M.-F., 2005. Is soil carbon mostly root carbon? Mechanisms for a specific stabilisation. Plant Soil 269, 341-356.

Rivas-Martínez, S., Rivas-Sáenz, S., 2016. Worldwide bioclimatic classification system, Phytosociological Research Center, Spain. http://www.globalbioclimatics.org

Rodríguez Martín, J.A., Álvaro-Fuentes, J., Gonzalo, J., Gil, C., Ramos-Miras, J.J., Grau Corbí, J.M., Boluda, R., 2016. Assessment of the soil organic carbon stock in Spain. Geoderma 264, 117-125.

Rynk, R., van de Kamp, M., Willson, G.B., Singley, M.E., Richard, T.L., Kolega, J.J., Gouin, F.R., Laliberty, Jr., L., Day, K., Murphy, D.W., Hoitink, H.A.J., Brinton, W.F., 1992. On-farm composting handbook. NRAES, Cornell University, Ithaca, NY.

Sanderman, J., Chappell, A., 2013. Uncertainty in soil carbon accounting due to unrecognized soil erosion. Glob. Chang. Biol. 19, 264-272.

Sanz-Cobena, A., Lassaletta, L., Estellés, F., Del Prado, A., Guardia, G., Abalos, D., Aguilera, E., Pardo, G., Vallejo, A., Sutton, M.A., Garnier, J., Billen, G., 2014. Yield-scaled mitigation of ammonia emission from $\mathrm{N}$ fertilization: the Spanish case. Environ. Res. Lett. 9, 125005.

Schader, C., Muller, A., Scialabba, N.E.-H., Hecht, J., Isensee, A., Erb, K.-H., Smith, P., Makkar, H.P.S., Klocke, P., Leiber, F., Schwegler, P., Stolze, M., Niggli, U., 2015. Impacts of feeding less foodcompeting feedstuffs to livestock on global food system sustainability. J. R. Soc. Interface 12 , 20150891. 
Scherr, S.J., Shames, S., Friedman, R., 2012. From climate-smart agriculture to climate-smart landscapes. Agric. Food Secur. 1, 12.

Senapati, N., Hulugalle, N.R., Smith, P., Wilson, B.R., Yeluripati, J.B., Daniel, H., Ghosh, S., Lockwood, P., 2014. Modelling soil organic carbon storage with RothC in irrigated Vertisols under cotton cropping systems in the sub-tropics. Soil Tillage Res. 143, 38-49.

Skjemstad, J.O., Spouncer, L.R., Cowie, B., Swift, R.S., 2004. Calibration of the Rothamsted organic carbon turnover model (RothC ver. 26.3), using measurable soil organic carbon pools. Aust. J. Soil Res. 42, 79-88.

Smith, J., Smith, P., Wattenbach, M., Zaehle, S., Hiederer, R., Jones, R.J.A., Montanarella, L., Rounsevell, M.D.A., Reginster, I., Ewert, F., 2005. Projected changes in mineral soil carbon of European croplands and grasslands, 1990-2080. Glob. Chang. Biol. 11, 2141-2152.

Smith, P., 2004. Carbon sequestration in croplands: the potential in Europe and the global context. Eur. J. Agron. 20, 229-236.

Smith, P., Bustamante, M., Ahammad, H., Clark, H., Dong, H., Elsiddig, E., AHaberl, H., Harper, R., House, J., Jafari, M., Masera, O., Mbow, C., Ravindranath, N.H., Rice, C.W., Robledo-Abad, C., Romanovskaya, A., Sperling, F., Tubiello, F., 2014. Agriculture, Forestry and Other Land Use (AFOLU), in: Edenhofer, O., Pichs-Madruga, R., Sokona, Y. Farahani, E. Kadner, S. Seyboth K., Adler, A., Baum, I., Brunner, S., Eickemeier, P., Kriemann, B., Savolainen, J., Schlömer, S., von Stechow, C., Zwickel, T., Minx J.C. (Eds.), IPCC 2014: Climate Change 2014: Mitigation of Climate Change. Contribution of Working Group III to the Fifth Assessment Report of the Intergovernmental Panel on Climate Change. Cambridge University Press, Cambridge, United Kingdom and New York, NY, USA.

Smith, P., Smith, J.U., Powlson, D.S., McGill, W.B., Arah, J.R.M., Chertov, O.G., Coleman, K., Franko, U., Frolking, S., Jenkinson, D.S., Jensen, L.S., Kelly, R.H., Klein-Gunnewiek, H., Komarov, A.S., Li, C., Molina, J.A.E., Mueller, T., Parton, W.J., Thornley, J.H.M., Whitmore, A.P., 1997. A comparison of the performance of nine soil organic matter models using datasets from seven long-term experiments. Geoderma 81, 153-225.

Soil Survey Staff. 2014. Keys to Soil Taxonomy, 12th ed. USDA-Natural Resources Conservation Service, Washington, DC.

Sollins, P., Homann, P., Caldwell, B.A., 1996. Stabilization and destabilization of soil organic matter: mechanisms and controls. Geoderma 74, 65-105.

Styles, D., Gibbons, J., Williams, A.P., Stichnothe, H., Chadwick, D.R., Healey, J.R., 2015. Cattle feed or bioenergy? Consequential life cycle assessment of biogas feedstock options on dairy farms. GCB Bioenergy 7, 1034-1049.

Tate, K.., Scott, N.., Parshotam, A., Brown, L., Wilde, R.., Giltrap, D.., Trustrum, N.., Gomez, B., Ross, D.., 2000. A multi-scale analysis of a terrestrial carbon budget. Agric. Ecosyst. Environ. 82, 229-246.

Trost, B., Prochnow, A., Drastig, K., Meyer-Aurich, A., Ellmer, F., Baumecker, M., 2013. Irrigation, soil organic carbon and $\mathrm{N}_{2} \mathrm{O}$ emissions. A review. Agron. Sustain. Dev. 33, 733-749. 
UNFCCC, 2014.

http://unfccc.int/national_reports/annex_i_ghg_inventories/national_inventories_submissions /items/8108.php (accessed February, 2016).

Vallejo, A., Skiba, U.M., García-Torres, L., Arce, A., López-Fernández, S., Sánchez-Martín, L., 2006. Nitrogen oxides emission from soils bearing a potato crop as influenced by fertilization with treated pig slurries and composts. Soil Biol. Biochem. 38, 2782-2793.

VandenBygaart, A.J., Bremer, E., McConkey, B.G., Ellert, B.H., Janzen, H.H., Angers, D.A., Carter, M.R., Drury, C.F., Lafond, G.P., McKenzie, R.H., 2011. Impact of sampling depth on differences in soil carbon stocks in long-term agroecosystem experiments. Soil Sci. Soc. Am. J. 75, 226-234.

Wutzler, T., Reichstein, M., 2007. Soils apart from equilibrium - consequences for soil carbon balance modelling. Biogeosciences 4, 125-136.

Yokozawa, M., Shirato, Y., Sakamoto, T., Yonemura, S., Nakai, M., Ohkura, T., 2010. Use of the RothC model to estimate the carbon sequestration potential of organic matter application in Japanese arable soils. Soil Sci. Plant Nutr. 56, 168-176. 